\title{
Revised structure and stratigraphy of the northwestern Repparfjord Tectonic Window, northern Norway
}

\author{
Espen Torgersen 1,2, Giulio Viola',2 \& Jan Sverre Sandstad' \\ ${ }^{1}$ Geological Survey of Norway, Pb 6315 Sluppen, 7491 Trondheim, Norway. \\ ${ }^{2}$ Department of Geology and Mineral Resources Engineering, Norwegian University of Science and Technology, Sem Selands veg 1, 7491 Trondheim, Norway. \\ E-mail corresponding author(Espen Torgersen): espen.torgersen@ngu.no
}

\begin{abstract}
The Repparfjord Tectonic Window (RTW) consists of a $~ 8$ km-thick low-grade, weakly deformed Early Palaeoproterozoic volcano-sedimentary succession that hosts abundant $\mathrm{Cu}$ mineralisations. Two major, sediment-hosted, $\mathrm{Cu}$-deposits occur in the Saltvatnet Group, a $<6 \mathrm{~km}$-thick sequence of mainly coarse-grained clastic rocks that forms the core subject of the present study. Results from new mapping, structural analysis and whole-rock geochemistry from the northwestern part of the RTW are presented and used in association with high-resolution geophysical data to propose a revised stratigraphy of the Repparfjord volcano-sedimentary succession and its tectonic and geodynamic settings. The Saltvatnet Group is better characterised as containing four formations, now including also the uppermost volcaniclastic siltstones and dolostone members of the herein newly defined Gorahatjohka Formation. Field oberservations and structural analysis show that the current geometry of the Saltvatnet Group is that of a km-scale, upright, NE-SW-trending anticline, the Ulveryggen anticline, cored by the Saltvatnet Group, which thus represents the lowermost exposed rocks of the RTW. New and existing geochemical data are used to demonstrate that the two volcanic-dominated Nussir and Holmvatnet groups, which crop out on either side of the Ulveryggen anticline, have similar geochemical character and can be interpreted as temporal and lateral correlatives. The basaltic Ulveryggen intrusions within the Saltvatnet Group are geochemically different from any other igneous rocks in the RTW, suggesting that these intruded prior to the volcanic-dominated groups in the RTW. The revised stratigraphy of the RTW is interpreted as reflecting deposition and volcanism in an evolving continental back-arc, which contrasts with the purely intraplate rift setting inferred for most parts of the Fennoscandian Shield in the Early Palaeoproterozoic.
\end{abstract}

Keywords: Structure, Stratigraphy, Geochemistry, Sediment-hosted copper, Nussir, Ulveryggen, Finnmark, Fennoscandian Shield

Received 14. January 2016 / Accepted 19. February 2016 / Published online 20. April 2016

\section{Introduction}

The Repparfjord Tectonic Window (RTW) is situated within the Scandinavian Caledonides in Finnmark, northern Norway, and comprises primarily a $\sim 8 \mathrm{~km}$-thick, Early Palaeoproterozoic, volcano-sedimentary succession. It represents the northwesternmost exposed termination of the Fennoscandian Shield and is generally correlated with the nearby Alta-Kvænangen Tectonic Window and the Kautokeino and Central Lapland greenstone belts to the south (Fig. 1A; Pharaoh \& Pearce, 1984; Siedlecka et al., 1985; Pharaoh \& Brewer, 1990).
The Early Palaeoproterozoic succession is here referred to as the Repparfjord volcano-sedimentary succession and comprises a remarkable variety of low-grade, weakly deformed supracrustal rocks that still preserve abundant primary sedimentary and igneous structures (Reitan, 1963; Jansen, 1976; Rhodes, 1976; Pharaoh et al., 1983; Nilsen \& Nilsson, 1996). The generally agreed upon stratigraphy, formed by four groups and eleven formations, was established by Pharaoh et al. (1983) as a revision of the original stratigraphy by Reitan (1963). The Saltvatnet Group is an important part thereof and forms a 3 to 6 $\mathrm{km}$-wide, NE-SW-trending belt of clastic rocks bounded

Torgersen, E., Viola, G. \& Sandstad, J.S. 2015: Revised structure and stratigraphy of the northwestern Repparfjord Tectonic Window, northern Norway. Norwegian Journal of Geology 95, 397-421. http://dx.doi.org/10.17850/njg95-3-06. 


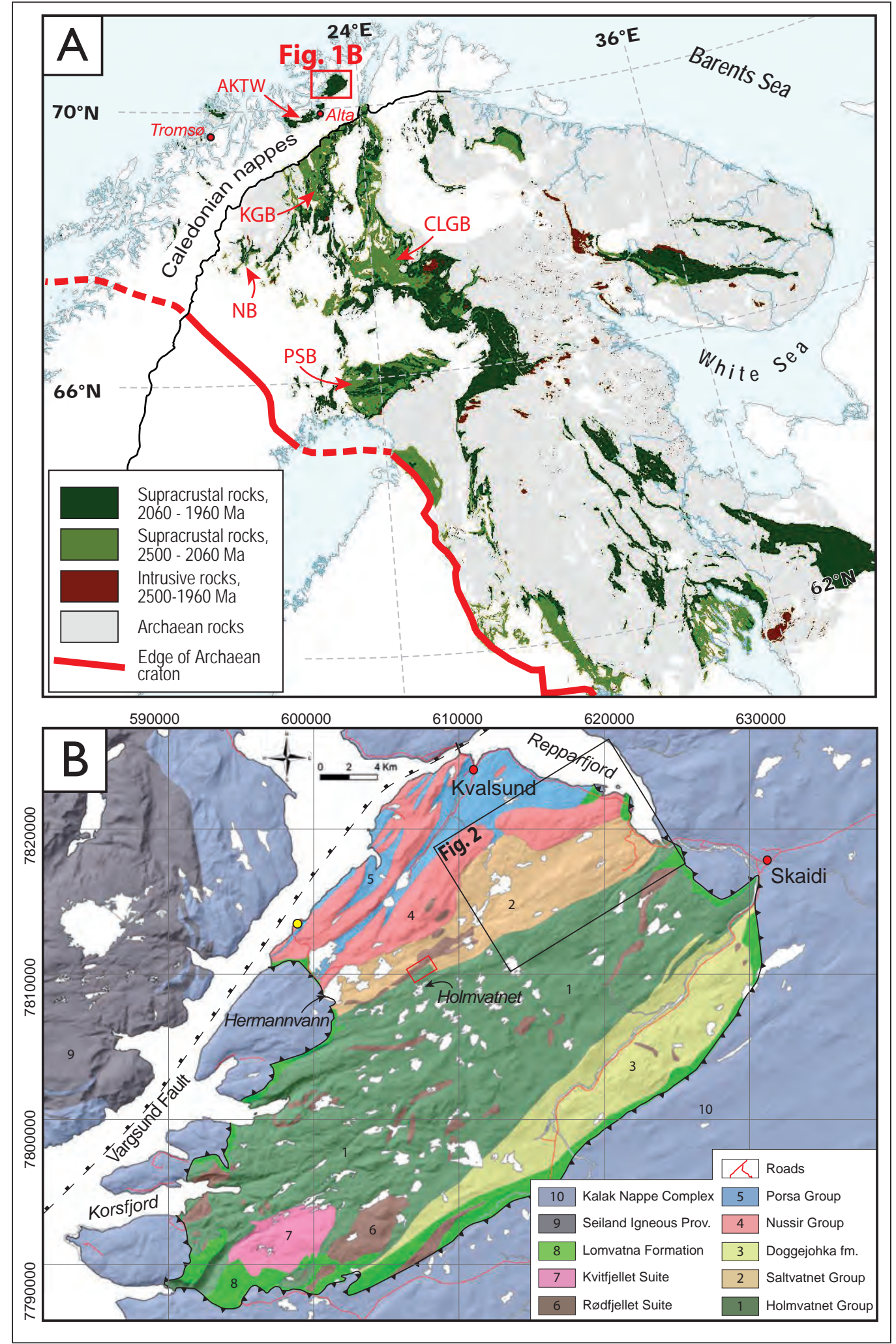

Figure 1. (A) Overview geological map of the northern part of the Fennoscandian Shield showing the distribution of Early Palaeoproterozoic supracrustal sequences and intrusive suites. Abbreviations: AKTW - Alta-Kvenangen Tectonic Window, KGB - Kautokeino Greenstone Belt, CLGB - Central Lapland Greenstone Belt, NB - Norrbotten Belt, PSB - Peräpohja Schist Belt. Map modified from Melezhik \& Hanski (2013a), based on Koistinen et al. (2001). (B) Simplified geological map of the Repparfjord Tectonic Window, which represents the northwesternmost exposed volcano-sedimentary succession of the Fennoscandian Shield (1:500,000; Siedlecka \& Roberts, 1996). Black rectangle: Focus area of this study (see Fig. 2). Red rectangle: Area from which key constraints on the Holmvatnet-Saltvatnet contact relationship are derived (e.g., Fig. 8D, E). Yellow dot: Location of sample ETO_106, which is outside of the primary focus area. Coordinates in WGS84/UTM zone 34N. 
by mafic lavas and tuffs of the Nussir and Holmvatnet groups on either side. It has been of significant economic interest since the 1950s as it comprises two major, sediment-hosted, $\mathrm{Cu}$-deposits, the dolarenite-hosted Nussir- and the conglomerate-sandstone-hosted Ulveryggen deposit $(66 \mathrm{Mt}$ at $1.15 \% \mathrm{Cu}$ and $7.7 \mathrm{Mt}$ at $0.8 \% \mathrm{Cu}$, respectively; Figs. 2A \& 3B; Nussir ASA, 2015).

Classically, the Saltvatnet Group is interpreted as a NWdipping monoclinal succession of intracontinental rift sediments sandwiched between the Holmvatnet Group stratigraphically below and the Nussir Group above (Pharaoh et al., 1983).

Our study area is situated in the northwestern part of the RTW (Figs. 1B \& 2A). We present new field observations and structural constraints from several traverses and key geological contacts that we have used to reinvestigate the stratigraphy and geometry of the Saltvatnet Group, its stratigraphic relationship with the neighbouring volcanic groups and its paleotectonic setting.

Field constraints represent the main evidence used to propose our revision of the stratigraphy of the Repparfjord volcano-sedimentary succession. To strengthen the reinterpretation of the stratigraphy, we run wholerock major and trace element analyses on six samples of the Nussir Group and three samples of mafic dykes/ sills in the Saltvatnet Group (the Ulveryggen intrusions). These new results are compared to existing data from the Holmvatnet Group in order to evaluate their geochemical characteristics and to infer a tectonic setting. Based on the presented data, as well as recently published geochronological constraints (Perelló et al., 2015; Torgersen et al., 2015), we suggest a new interpretation of the Early Palaeoproterozoic evolution of the Repparfjord volcanosedimentary succession. The primary motivation for this work was to establish a modern geological model of the Saltvatnet Group to be used as a conceptual framework in future ore-genetic studies of sediment-hosted $\mathrm{Cu}$-deposits. In addition, the proposed revision of the stratigraphy of the Repparfjord volcano-sedimentary succession has implications for regional geological correlations, and thus on the assessment of sediment-hosted $\mathrm{Cu}$ potential of the northern Fennoscandian Shield.

\section{Geological background and the classic stratigraphy of the Repparfjord volcano-sedimentary succession}

The Repparfjord Tectonic Window (RTW), covering an area of about $20 \times 50 \mathrm{~km}$, is situated just north of the town of Alta in Finnmark (Fig. 1). It is comprised primarily of a $\sim 8 \mathrm{~km}$-thick succession of Early Palaeoproterozoic, low-grade, weakly deformed volcano-sedimentary rocks (Reitan, 1963; Jansen, 1976; Rhodes, 1976; Pharaoh et al., 1983; Nilsen \& Nilsson, 1996; Viola et al., 2008). Pharaoh et al. (1983) indentified four groups and eleven formations within this succession, together constituting his
Raipas Supergroup (Fig. 3A; all local names in this publication are spelled following Nystuen (1986) and the 2015 version of the online topographic map of the Norwegian Mapping Authority available at www.norgeskart.no). The Holmvatnet Group was interpreted as the lowermost exposed stratigraphic group by Pharaoh et al. (op.cit.). It is dominated by tholeiitic to calc-alkaline basaltic, andesitic and rhyolitic volcanic and volcaniclastic rocks, which are separated into three formations (the Markfjellet, Båtdalselv and Magerfjellet formations; Pharaoh et al., 1983). Jensen (1996), on the other hand, defined seven formations to describe the Holmvatnet Group. Its detailed stratigraphy is not yet fully constrained, but Pharaoh et al. (1983) placed the Markfjellet Formation at the base of the group based on the presence of gneiss and granite boulders in it. Accordingly, the tholeiitic basaltic lavas and tuffs of the Magerfjellet Formation, situated at the margins of the Holmvatnet Group, are interpreted as the uppermost formation (Fig. 3A).

The Holmvatnet Group, according to Pharaoh et al. (1983), is stratigraphically overlain (possibly unconformably) by the clastic rocks of the Saltvatnet Group (Fig. $3 \mathrm{~A})$. Coarse-grained arkosic sandstones of the Ulveryggen Formation form the lowermost part of the group (Pharaoh et al., 1983). Hosted in Ulveryggen Formation is the Ulveryggen deposit, a sediment-hosted Cu-deposit consisting of several saucer-shaped ore bodies (Stribrny, 1985; Torgersen et al., 2014a). The Ulveryggen Formation is overlain by two distinct volcanoclastic conglomerates, the lower greenstone clast-dominated Dypelva Formation and the overlying purple, dacite clast-dominated Stangvatnet Formation. The Doggejohka formation southeast of the Holmvatnet Group comprises quartzitic metasandstones and is classically correlated with the Ulveryggen Formation (Fig. 1B; Pharaoh et al., 1983). A more detailed description of the internal stratigraphy of the Saltvatnet Group is provided in the following section.

The Saltvatnet Group is overlain by tholeiitic basaltic tuffs and lavas of the Nussir Group, subdivided internally into the Krokvatnet Formation (green tuffs and tuffites) and the Svartfjellet Formation, with massive, pillowed and amygdaloidal lavas (Fig. 3A; Pharaoh et al., 1983; Pharaoh, 1985b). The Nussir Cu-deposit, which also contains significant Ag concentrations, is hosted in thin, laterally extensive, dolarenite beds in the lower part of what Pharaoh et al. (1983) defined as the Krokvatnet Formation (Nilsen \& Martinsen, 2009; Sandstad, 2010; Perelló et al., 2015). U-Pb dating of zircons from a mafic tuffite in this formation yielded a maximum formation age of $2073+23 /-12 \mathrm{Ma}$ (Perelló et al., 2015). A minimum age of $2069 \pm 14 \mathrm{Ma}$ is constrained by Re-Os sulphide dating in carbonate veins cutting the Nussir Group (Torgersen et al., 2015). The Nussir Group basaltic lavas are overlain by stromatolitic dolostones, graphitic slates and green tuffs and tuffites of the Porsa Group, which is divided into three formations (the Vargsund, Kvalsund and Bierajávri formations) and represents the uppermost exposed unit 


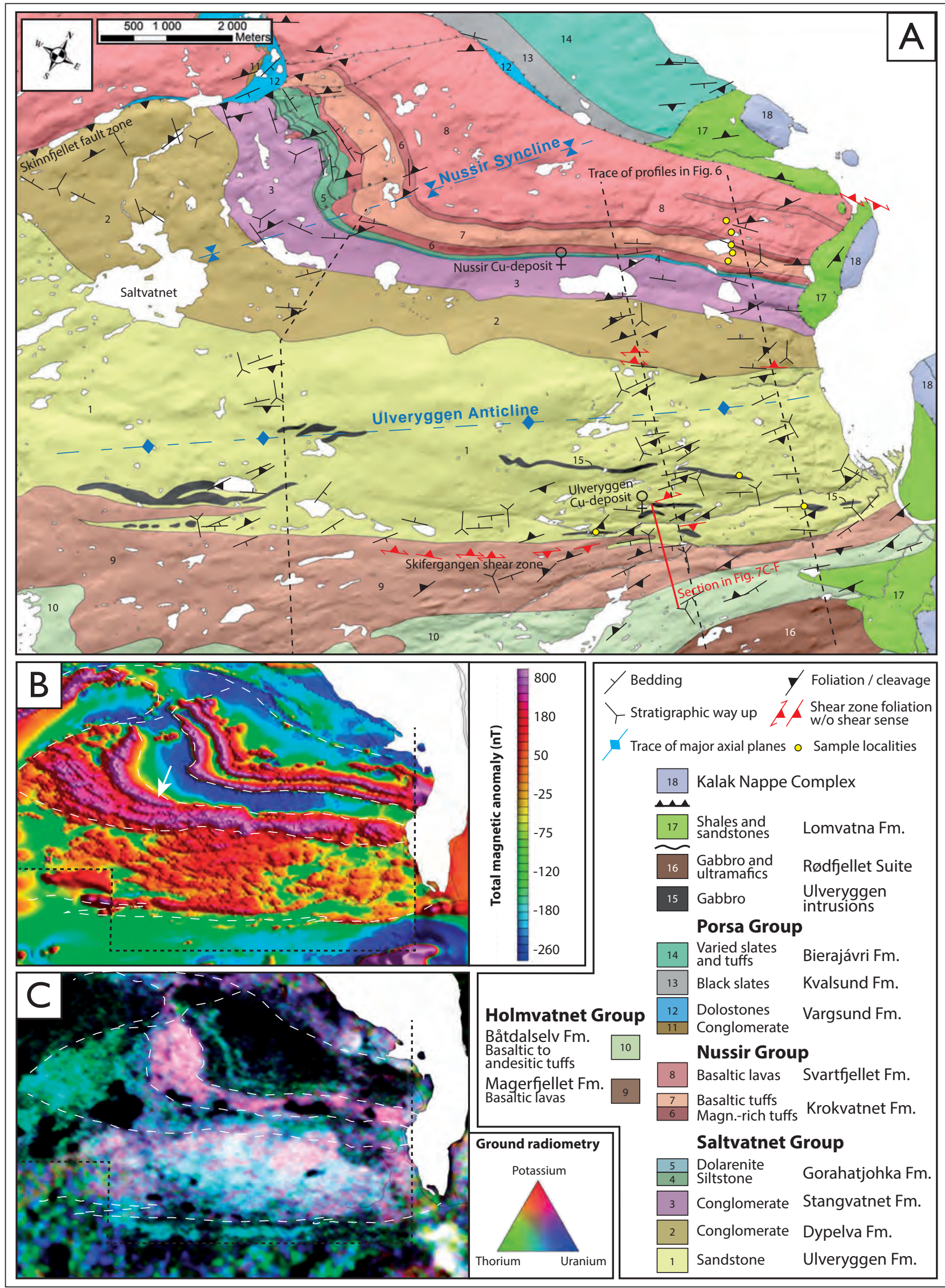

Figure 2. (A) Detailed map of the northern Repparfjord Tectonic Window. Yellow dots mark the location of samples for geochemical analysis. Black stippled lines show the trace of profiles in Fig. 6. (B) Total magnetic anomaly map of the same area as in (A). (C) Ground radiometric K, Th and $U$ concentrations plotted as a ternary blend. $(B, C)$ Very high-resolution airborne geophysics covers most of the study area $(25 \mathrm{~m}$ cell size, 100 $m$ line spacing, $65 \mathrm{~m}$ flying altitude; Heincke et al., 2008), but some parts (below and right of black stippled line) have slightly lower resolution (50 $m$ cell size, $200 \mathrm{~m}$ line spacing, $88 \mathrm{~m}$ flying altitude; Ofstad et al., 2013). White stippled lines represent major lithological and structural contacts. 


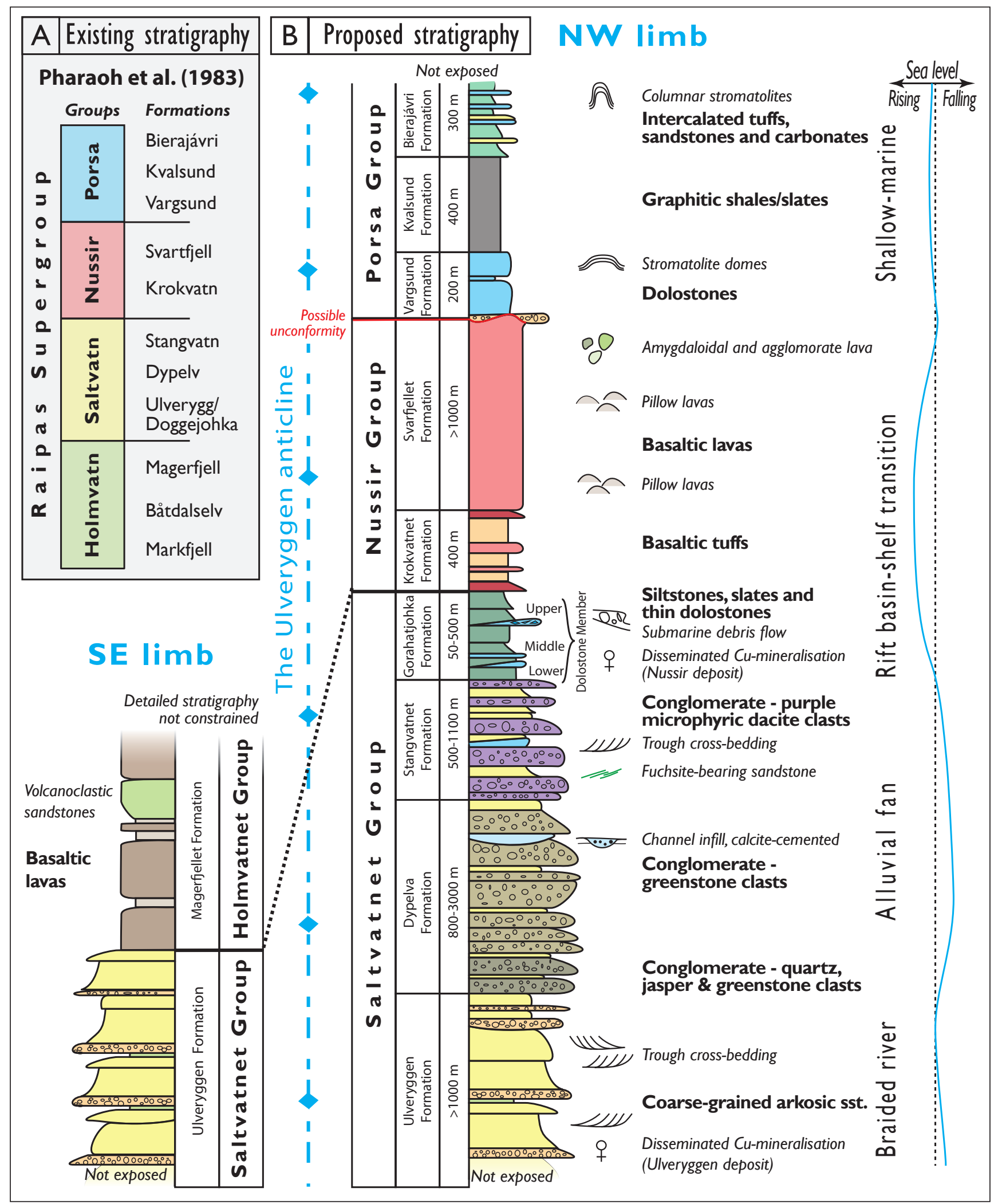

Figure 3. (A) Existing stratigraphy of the Repparfjord volcano-sedimentary succession as defined by Pharaoh et al. (1983). (B) Revised stratigraphic column of the Repparfjord volcano-sedimentary succession, reflecting the lateral facies variations on either side of the Ulveryggen anticline.

in the Repparfjord volcano-sedimentary succession (Fig. $3 \mathrm{~A})$. The contact with the underlying Nussir Group is in most places tectonic due to bedding-parallel thrusting and transposition along large fold limbs (Torgersen \&
Viola, 2014). In the fold hinges, however, a basal polymict conglomerate is locally preserved between the Nussir and Porsa groups, indicating that the Porsa sediments were possibly deposited on an erosional surface on top of the 
Nussir basaltic lavas (Pharaoh et al., 1983). The age span of this hiatus is not known.

The Repparfjord volcano-sedimentary succession is cut by two intrusive suites of presumed Palaeoproterozoic age (the Rødfjellet [Raudfjell] and Kvitfjellet suites; Fig. 1; Pharaoh et al., 1983). Several mafic intrusions are also found within the Ulveryggen Formation, particularly in the area studied here (Fig. 2A). They are thin, elongated, NE-SW-trending intrusions, which are correlated to the Rødfjellet suite by Pharaoh et al. (1983) and referred to as diorite-porphyrites by Stribrny (1985). They are informally referred to herein as the Ulveryggen intrusions.

Both the supracrustal sequence and the intrusions were deformed and metamorphosed at greenschist- to lower amphibolites-facies conditions during the Svecofennian orogeny approximately $1840 \mathrm{Ma}$ ago, with an apparent increase in metamorphic grade and deformation towards the southeast (Pharaoh et al., 1982). Overall NW-SE compression caused large-scale upright folding of the entire sequence around subhorizontal to gently NE- and SW-plunging axes and the development of a subvertical NE-SW-striking axial planar cleavage (Pharaoh et al., 1983; Kjøll et al., 2015).

Generally, the RTW is correlated with other Palaeoproterozoic greenstone belts in nearby tectonic windows and the large basement areas in Finnmarksvidda, northern Finland, Sweden and Karelian Russia (Pharaoh \& Pearce, 1984; Siedlecka et al., 1985; Pharaoh et al., 1987; Pharaoh \& Brewer, 1990). These greenstone belts developed during protracted intraplate rifting, and progressive fragmentation of the Fennoscandian Shield between approximately 2.4 and $2.0 \mathrm{Ga}$. Rifting was eventually succeeded by ocean closure and collision during the Svecofennian orogeny (Melezhik \& Hanski, 2013b). Although recent radiometric age constraints confirm that the Repparford volcanosedimentary succession is of Early Palaeoproterozoic age (Perelló et al., 2015; Torgersen et al., 2015), a comparison with new geochronological constraints from nearby greenstone belts in northern Norway (e.g., Melezhik et al., 2015; Bingen et al., 2015) challenges the classic, lithologybased correlations. A direct correlation with neighbouring greenstone belts is not supported by sedimentological characteristics and stable isotope composition of carbonate rocks in the RTW (Torgersen, 2015).

Along the periphery of the RTW, a thin unconformable cover sequence, the Lomvatna Formation, crops out (Fig. 1B; Pharaoh, 1985a). It is composed of pebble conglomerates and feldspathic arenites that pass upward into silty slates and is typically correlated with the Neoproterozoic sedimentary rocks found elsewhere in northern Norway (Pharaoh, 1985a). The Lomvatna Formation was penetratively deformed during the Silurian Caledonian orogeny, which involved SE- to E-directed emplacement of nappes onto the western margin of the Fennoscandian Shield (Reitan, 1963; Rhodes, 1976; Rice, 1998; Gee et al., 2008). In the western part of the window, the Lomvatna Formation is in a parautochthonous position, tightly to isoclinally folded and is characterised by the complete rejuvenation of mica $\mathrm{K}-\mathrm{Ar}$ ages (at approximately 430-410 Ma; Dallmeyer et al., 1988). Although the Palaeoproterozoic rocks of the RTW are generally little affected by Caledonian deformation, recording subgreenschist-facies conditions (Dallmeyer et al., 1988) and still preserve primary sedimentary structures, significant Palaeozoic localised deformation was accommodated in the northwestern part of the window (Torgersen \& Viola, 2014; Kjøll et al., 2015). Here, a series of discrete thrusts developed on the limbs of Palaeoproterozoic folds (Pharaoh et al., 1983; Gayer et al., 1987), defining a large compressional imbricate stack, the Porsa Imbricate Stack (Torgersen \& Viola, 2014; Torgersen et al., 2014b; the Porsa Duplex of Gayer et al., 1987). The impact of the Caledonian orogeny on the RTW may, however, have been more significant than commonly assumed if the suggestion that the RTW is a far-travelled allochthonous basement horse within the Caledonian nappes is correct (e.g., Gayer et al., 1987; Rice, 2013).

\section{Towards a new stratigraphy of the northwestern RTW: New field constraints and structural analysis}

Based on new field and geochemical data, structural investigations and new high-resolution potential field geophysics from mainly the northeastern part of the Saltvatnet Group (Figs. 1B \& 2A; Heincke et al., 2008; Viola et al., 2008; Ofstad et al., 2013) we present below the rationale for a new stratigraphy of the northwestern RTW. We discuss our results in three sections that deal with 1) the stratigraphy of the Saltvatnet Group, 2) its structural framework and 3) its stratigraphic relationship with the Holmvatnet Group. Whole-rock geochemical data on the Nussir Group and Ulveryggen intrusions are presented in a following section.

\section{Reassessing the stratigraphy of the Saltvatnet Group}

According to the commonly accepted stratigraphy, the Saltvatnet Group comprises three formations, the Ulveryggen, the Dypelva and the Stangvatnet formations. Its conformable, yet locally tectonically reworked, contact with the overlying Nussir Group is placed at the top of the purple, arkosic sandstone capping the Stangvatnet Formation (Pharaoh et al., 1983).

The Ulveryggen Formation represents the lowermost $\sim 1000 \mathrm{~m}$ of the Saltvatnet Group (Fig. 3B). It is dominated by coarse-grained, well-bedded, arkosic to quartzitic sandstones (bed thickness $\sim 0.5-2 \mathrm{~m}$ ) that commonly preserve upward-fining cycles with thin quartz-pebble 

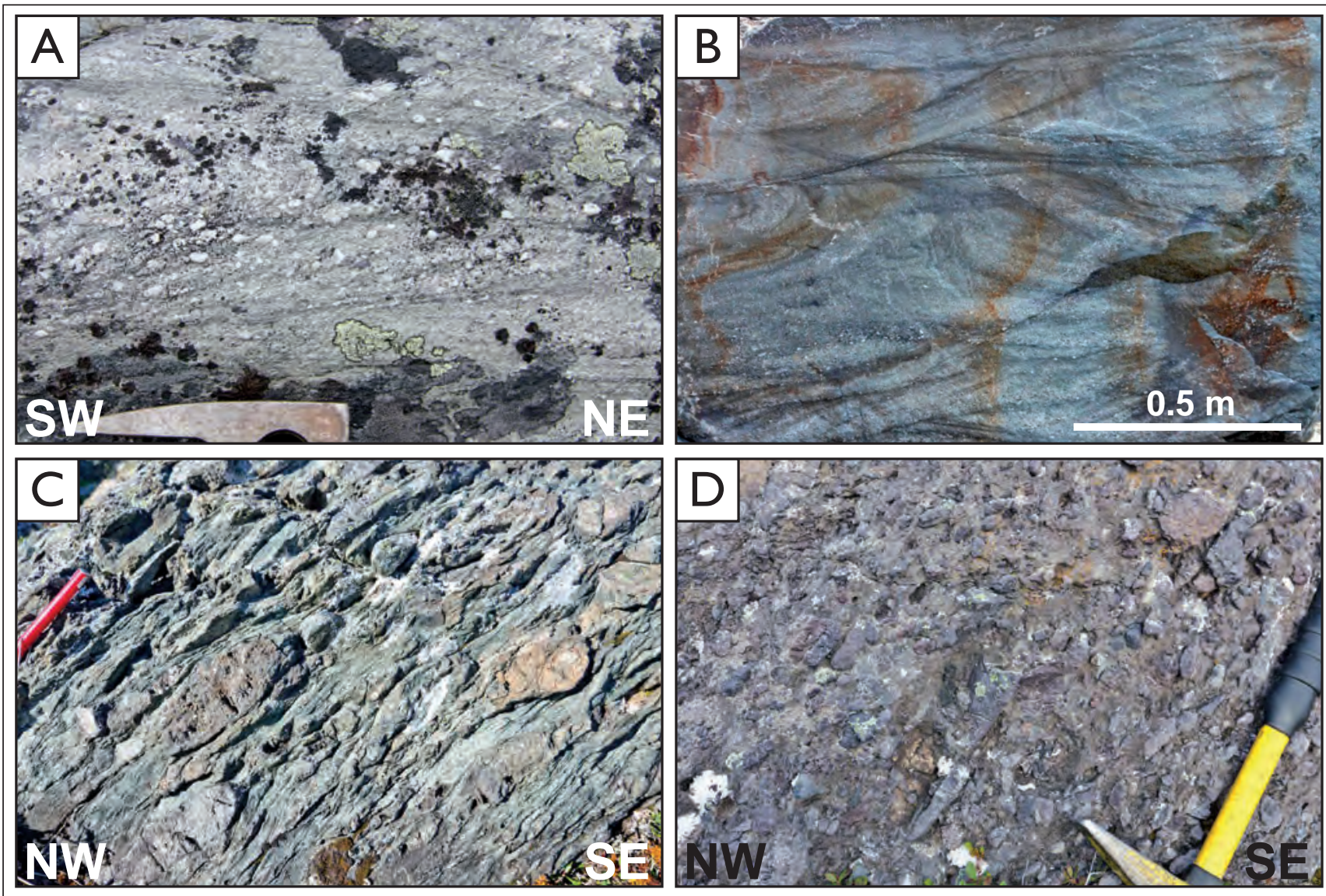

Figure 4. Typical sedimentary features of the Ulveryggen, Dypelva and Stangvatnet formations. (A) Light grey to white, bedded arkosic sandstone with quartz-pebble levels (621162E/7817630N). (B) Trough cross-bedding in a sandstone block at the Ulveryggen Cu-deposit (621205E/7817019N). (C) Strongly flattened, green, poorly sorted, volcaniclastic conglomerate of the Dypelva Formation (619644E/7819177N).

(D) Undeformed, purple, monomict conglomerate in the Stangvatnet Formation (620625E/7820671N).

conglomeratic levels at the base and greenish siltstones at the top (Fig. 4A, B). Thicker quartz-pebble conglomerate beds $(<2 \mathrm{~m})$ are, in places, common and trough cross bedding is observed throughout (Fig. 4B). The formation is interpreted as coast-marginal braided river deposits (Pharaoh et al., 1983). The transition to the overlying mainly volcaniclastic Dypelva Formation conglomerate is characterized by a gradual upward increase of conglomerate beds (1-3 m thick) arranged in regular cycles with interbedded siltstones and a diversification of clast material to comprise vein quartz, greenstone, jasper and scattered carbonates and magnetite-rich clasts (Fig. 3B). This polymict conglomerate constitutes the lowermost 100 stratigraphic metres of the Dypelva Formation, where it occurs in thick (1-10 m), poorly sorted beds with erosional bases. Above it, the Dypelva Formation contains green, poorly bedded and unsorted monomict conglomerates, dominated by greenstone clasts in a green matrix (Fig. 3B). The conglomerate is locally intensively foliated (subvertical NE-SW-striking cleavage) and contains strongly flattened clasts oriented parallel to the foliation (Fig. 4C). Upwards there is a rapid transition to the purple, well-bedded, monomict volcaniclastic conglomerate and interbedded arkosic sandstones of the Stangvatnet Formation. The purple-coloured clasts have a dacitic composition, are relatively K-rich (Reitan, 1963), and have a microporphyitic texture defined by $<1 \mathrm{~cm}$ feldspar laths. In contrast to clasts in the Dypelva Formation, they are relatively undeformed (Fig. 4D). Arkosic sandstones make up a laterally continuous and up to $100 \mathrm{~m}$-thick unit that contains sets of normally-graded beds with low-angle planar cross-stratification and notable flakes of bright green fuchsite (Cr-bearing mica).

The contact between the Dypelva and Stangvatnet formations is easily seen on high-resolution aeromagnetic and radiometric maps of the region (Fig. 2B, C) because of their significant compositional differences (magnetiterich greenstone clasts in the Dypelva Formation and hematite- and K-rich dacitic clasts in the Stangvatnet Formation; Fig. 2B, C). Both formations are interpreted as alluvial-fan deposits, formed by volcanic debris flows (Pharaoh et al., 1983) or subaerial mudflows (Rhodes, 1976), although in the Stangvatnet Formation the presence of trough cross-bedded arkosic sandstones indicates that at least part of this formation was deposited by ephemeral braided streams.

The total thickness of the Dypelva and Stangvatnet formations increases considerably along strike from approx- 
imately $1200 \mathrm{~m}$ in the east to about $4100 \mathrm{~m}$ in the west, where they terminate against the Skinnfjellet fault zone (Fig. 2A; Kjøll et al., 2015). A comparable thickness variation is also shown by the volcaniclastic siltstones (and sandstones) that conformably overlie the Stangvatnet Formation (varying from $\sim 50$ to $500 \mathrm{~m}$; Fig. 2A). These rocks were previously interpreted as part of the Nussir Group (Pharaoh, 1985b), but, as shown by the geophysical data (Fig. 2B, C), they have an identical radiometric and magnetic signature to the underlying Stangvatnet Formation, thus indicating that the two have similar bulk composition. This observation corroborates the field data (see below), and the volcaniclastic siltstones are thus interpreted as the fourth formation genetically associated with the Saltvatnet Group, herein named the 'Gorahatjohka Formation' after the small river flowing into the Repparfjord along its northeasternmost exposure. The Gorahatjohka Formation extends from the top of the uppermost bed of purple conglomerates to the base of the first layer of green magnetite-rich tuffite of the Nussir Group (Figs. 2 \& 3B). In detail, it consists of grey-green and purple carbonate-rich siltstones, indicating variable red-ox conditions during formation in relatively shallow water, and fine-grained sandstones with distinctive pale grey weathered surfaces (Fig. 5A, B), in addition to thin dolostone members. The siltstones in the middle part are relatively massive, whereas those at the base and top of the formation are well-bedded (bed thickness of 10 to 30 $\mathrm{cm})$ and internally finely laminated $(1-2 \mathrm{~cm}$ thick; Fig. 5B). Bedding and lamination are commonly disrupted by abundant, $1-5 \mathrm{~cm}$ long, randomly oriented, calcite veinlets that in places are oriented parallel to a subvertical NE-SW-striking cleavage (see next section). At one locality, the bedding is offset by a set of very discrete, subvertical, NE-SW-striking normal faults (Fig. 5A). Their relatively early timing is indicated by the fact that the fault surfaces are overprinted by a later tectonic cleavage.

Up to three, thin $(<5 \mathrm{~m})$, dolostone members occur within the Gorahatjohka Formation (Fig. 2A), informally defined in here as the Lower, Middle and Upper Dolostone Members (Fig. 3B). The Lower and Middle Members are the $\mathrm{Cu}$ - (and Ag-) mineralised units that have in the past been referred to collectively as the Nussir Dolomite (Nilsen \& Martinsen, 2009; Torgersen et al., 2014a). The Lower Member is present only in the thicker, western part of the formation (Fig. 2A), and is interpreted to taper out against the underlying conglomerates. The Middle Member, however, extends along the entire strike length of the formation. In the west, these two members are displaced by tens of metres along several discrete and subvertical reverse faults oriented NE-SW (Fig. 2A). The Lower and Middle Dolostone Members are mainly composed of white to light grey, fine-grained, massive to finely bedded $(<5 \mathrm{~cm})$ dolarenites (Fig. 5C). The ore minerals, mainly bornite, chalcocite and chalcopyrite ( \pm neodigenite), occur finely disseminated and commonly comprise interstitial grains and aggregates forming the matrix in the dolarenite, but are also found enriched in irregular quartz- and carbonate-rich veinlets and lenses. The contacts to the adjacent siltstones are transitional over $1-3 \mathrm{~m}$ and are defined by strongly foliated, dark grey, sericite-rich dolostones (Fig. 5C).

The Upper Member consists of dolobreccia and is found only in the western part, where it terminates against an inferred W-dipping normal fault in the east (Fig. 2A). This dolobreccia is $5-10 \mathrm{~m}$ thick and consists of angular, randomly oriented clasts of siltstone, bedded dolostone, quartz and jasper set in a dolomitic matrix (Fig. 5D). The contact to the underlying siltstones is generally planar and subparallel to the siltstone bedding, but locally the dolobreccia fills small discordant troughs (Fig. 5D). The partly erosive character and the chaotic appearance indicate that the dolobreccia possibly formed by submarine debris flows. In contrast to the Lower and Middle Dolostone Members, the Upper Member does not contain any $\mathrm{Cu}$ or $\mathrm{Ag}$ mineralisations.

The uppermost one to five metres of the Gorahatjohka Formation is composed of light grey, fine-grained, thinlybedded $(2-5 \mathrm{~cm})$ and normal-graded magnetite-rich siltstones interpreted as possible turbidite deposits (Fig. 5E). Planar, low-angle cross-bedding is observed locally (Fig. $5 \mathrm{E})$. In most places there is a gradual transition from the light-grey siltstones into the green, laminated magnetiterich tuffites that define the base of the Nussir Group. The lamination therein is invariably parallel to the bedding in the underlying siltstones, suggesting a primary stratigraphic relationship. In some localities, however, the rocks closest to the contact are strongly deformed, with a phyllonitic foliation dipping moderately to the $\mathrm{NW}$, and with asymmetric clasts, shear bands and dragging of the steep regional foliation indicating a reverse top-to-the-SE sense of movement (Fig. 5F). Shearing is, however, extremely localised along the contact and is therefore interpreted as representing only minor reactivation/tectonitisation of the primary lithological contact. Whereas Reitan (1963) suggested this contact to be a top-to-the-SE thrust, we prefer to interpret it essentially as a conformable stratigraphic contact, in agreement with Pharaoh et al. (1983).

\section{Structure of the Saltvatnet Group: the Ulveryggen anticline}

Detailed structural mapping was carried out along several traverses across the Saltvatnet Group. Bedding in the Saltvatnet Group generally strikes NE-SW, and a subvertical NE-SW-striking cleavage is developed in clay-rich lithologies throughout the group (Fig. 2A). Together they constrain folding by subhorizontal to shallowly NE-plunging upright folds (Fig. 6), which was also observed by Reitan (1963), Pharaoh et al. (1983) and Stribrny (1985). In map view, folding is most easily shown by the syncline defined by the Stangvatnet-Gorahatjohka and GorahatjohkaNussir contacts in the northernmost part of the study area (Nussir Syncline; Fig. 2A; Pharaoh et al., 1983). 

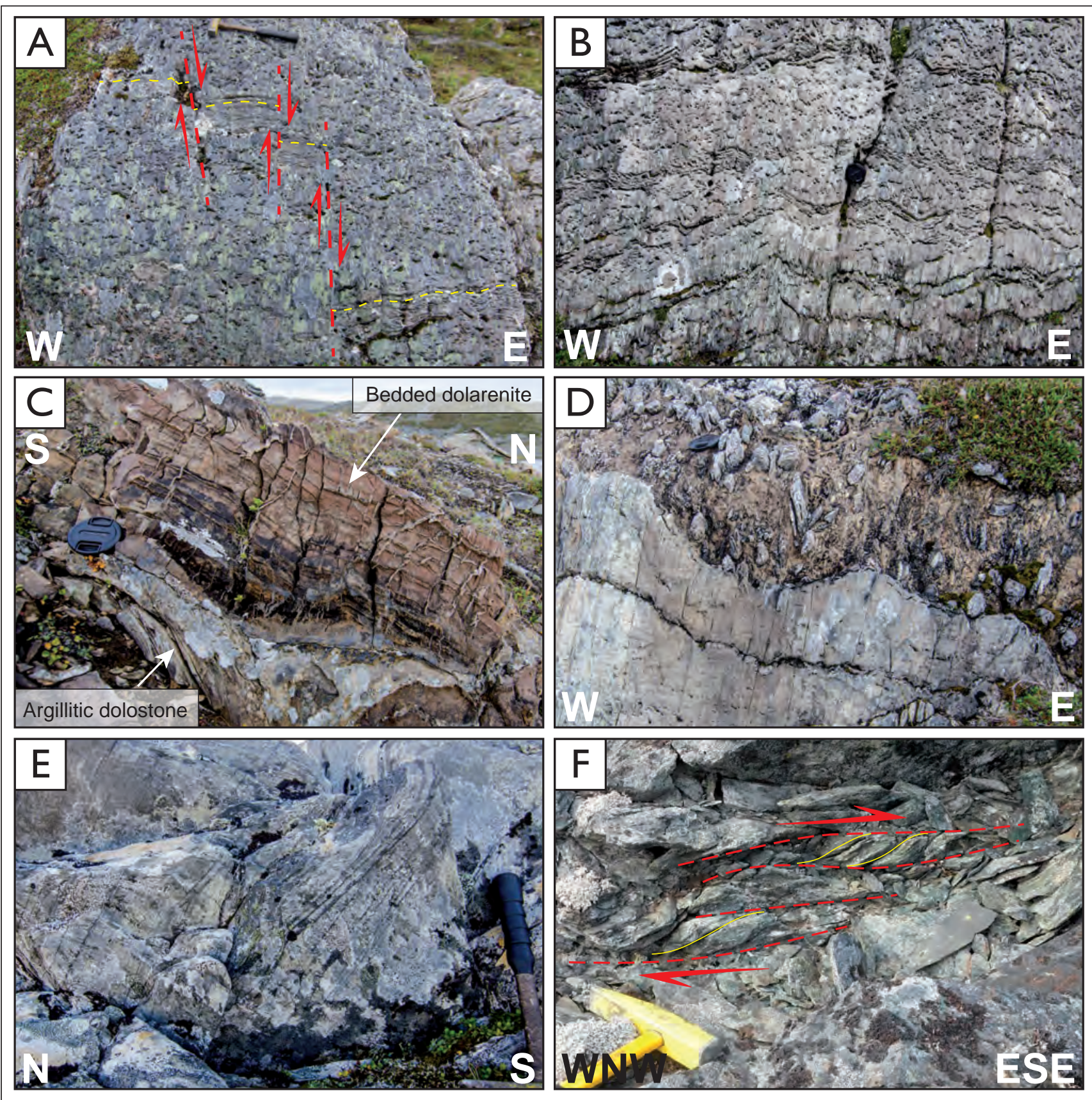

Figure 5. Sedimentological and structural features of the Gorahatjohka Formation, Saltvatnet Group. (A) Oblique pavement view of well-laminated siltstones displaced along discrete, subvertical, N-S-striking normal faults (613602E/7819797N). (B) Very open, upright, moderately NEplunging folds deforming finely bedded carbonate-rich siltstones with a very well developed subvertical, NE-SW-striking, axial planar cleavage. Surface pockmarks represent weathered-out calcite veinlets. Lens cap in the centre for scale (613671E/7819676N). (C) Finely laminated and well-bedded dolarenites above strongly foliated argillitic dolostones of the Middle Dolostone Member (614254E/7818875N). (D) Upper Dolobreccia Member comprising angular clasts of bedded dolostone, siltstone, quartz and jasper. The erosional contact of the dolobreccia against the underlying siltstones is interpreted to have formed during a subaqueous debris flow (614415E/7818803N). (E) Fine-grained, finely bedded and normally graded grey siltstones with magnetite-rich bases and metre-scale, low-angle cross-bedding at the uppermost part of the Gorahatjohka Formation (613678E/7819778N). (F) Localised top-to-the-ESE shear bands along the Saltvatnet-Nussir contact within a<1 m-thick, strongly sheared, phyllonitic zone (613818E/7819612N; UTM 34N).

New mapping reveals that the overall geometry of the Saltvatnet Group is that of a $\sim 3 \mathrm{~km}$-wavelength, open, upright, shallowly NE-plunging anticline (Figs. 2 \& 5), here called the Ulveryggen anticline. Superimposed on the regional Ulveryggen anticline are numerous parasitic folds with wavelengths of tens to hundreds of metres (Figs.
2A \& 6). These second-order folds are generally open, but tighter geometries are also present, especially around the Ulveryggen $\mathrm{Cu}$-deposit (Fig. 2A), as also noted by Pharaoh et al. (1983) and Stribrny (1985). Mesoscopic folds are only observed directly at very few localities, where the hinge zones of relatively tight upright folds are exposed. 
Common cross bedding and fining-upward cycles constrain the younging direction throughout the region and show that the stratigraphy is nowhere overturned. This is consistent with the angular relationship between bedding and the steeper axial planar cleavage (Figs. 5B, $6 \& 7 \mathrm{~A}$ ). Locally preserved striations suggest dip-slip movements along chlorite-coated bed-bed interfaces (Fig. 7B), indicative of flexural slip folding.
The upright anticlinal geometry of the Saltvatnet Group is the reason for the overall SE dip of the bedding towards the contact with the Holmvatnet Group, which suggests that the former group should rest beneath the latter (Fig. 6). Although there is a slight tightening of the folds within the Saltvatnet Group toward this contact, the axial planar attitude remains upright and bedding is never overturned. This is demonstrated by the observations made

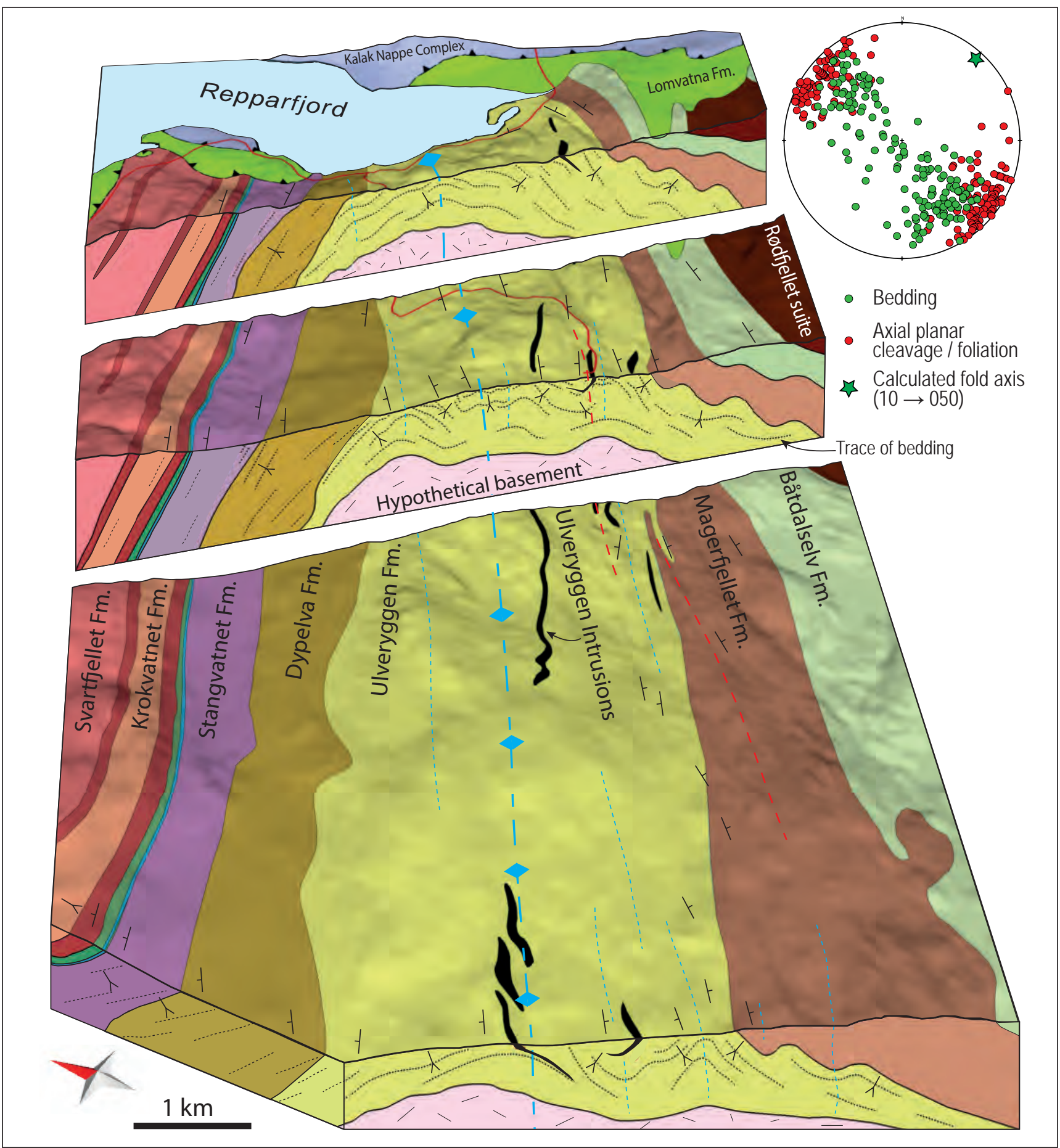

Figure 6. 3D-model of the geology across the Ulveryggen anticline. The geological profiles are based on three detailed mapping sections. Blue stippled lines represent axial planes, whereas red lines indicate the location of prominent shear zones. Lower-hemisphere projection of poles to bedding (green) and cleavage/foliation (red) along these three sections. Green star: Calculated fold axis orientation based on the bedding measurements. Legends as in Fig. 2A (pink colour for hypothetical basement). Figure produced with the Move software package (Midland Valley). 

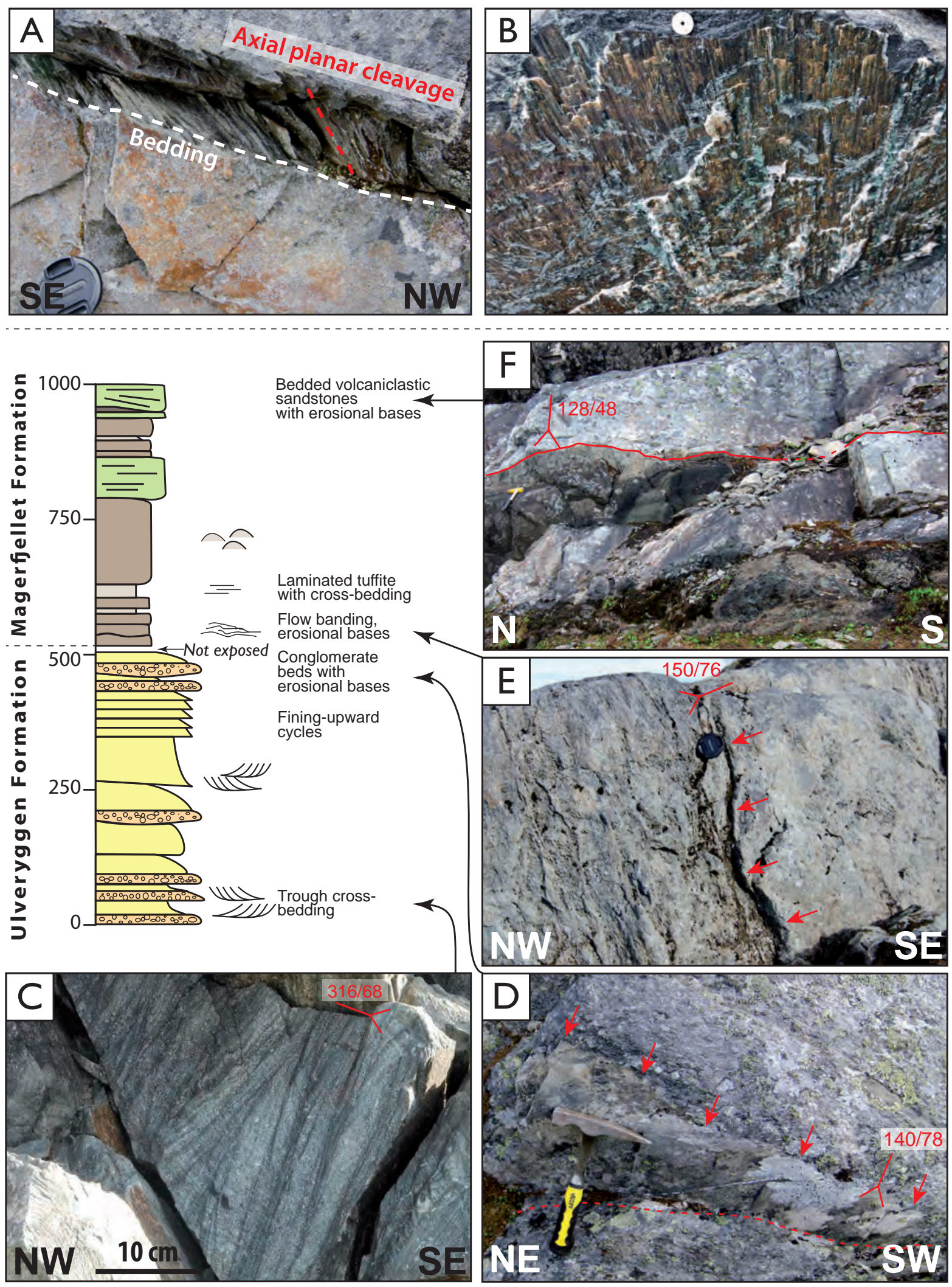

Figure 7. (A) Steeply NW-dipping axial planar slaty cleavage in a siltstone bed (620896E/7817916N). (B) Chlorite slickensides along bedding plane in a block at the Ulveryggen Cu-deposit attesting to flexural-slip folding (621205E/7817019N; UTM 34N). (C-F) Section across the Saltvatnet-Holmvatnet contact (see Fig. $2 \mathrm{~A}$ for its geographical location). (C) NW-dipping, coarse-grained arkosic sandstones with trough cross-bedding at the Ulveryggen Cu-deposit (621205E/7817019N). (D) Conglomerate infilling troughs in underlying silty sandstones. Younging direction to the southeast (621013E/7816322N). (E) SE-dipping contact between two lava flows $\sim 30 \mathrm{~m}$ away from the contact to the underlying Ulveryggen sandstones. The erosional contact between the flows indicates younging to the southeast (621531E/7816604N). (F) Two chlorite-rich tuffaceous layers cut discordantly by bedded volcaniclastic sandstones. Cutting relationships document younging to the southeast (621965E/7816266N; UTM 34N). 
along a geological section extending from the Ulveryggen $\mathrm{Cu}$-deposit well into the Holmvatnet Group (Fig. 7C-F). At the Ulveryggen $\mathrm{Cu}$-deposit, bedding dips to the NW and the stratigraphic way up is documented by abundant trough cross-beds (Fig. 7C) and subvertical axial planar cleavage (Fig. 2A; Sandstad et al., 2007). Southeast from the abandoned mine (Fig. 2A), bedding dips predominantly to the SE and remains the right way up, as shown by upward-fining cycles and conglomerate-filled troughs in sandstones and siltstones (Fig. 7D). Although the very contact between the Saltvatnet and Holmvatnet groups is not exposed along this section, banded lava flows and tuffites immediately above the extrapolated position of the contact have erosional bases and trough cross bedding giving an identical upward-younging direction as the trough cross-bedded sandstones in the Saltvatnet Group (Fig. 7E). A similar orientation and planar attitude is documented also elsewhere along the contact, for example at one locality where two, $\sim 1 \mathrm{~m}$-thick, chloriterich tuffaceous layers are discordantly overlain and laterally cut out by up to $10 \mathrm{~m}$-thick intervals of bedded volcaniclastic sandstones (Fig. 7F).

For these observations to be consistent with the classical interpretation of the Holmvatnet Group as the oldest group in the RTW, it would require the contact between the two groups to be tectonic and have accommodated a significant vertical displacement. Our observations from along this contact, however, indicate that this interpretation is not justified by the available evidence (see next section).

\section{The Saltvatnet-Holmvatnet contact}

The pronounced difference in colour between the greyish Ulveryggen Formation sandstones and the brownish Magerfjellet Formation basalts of the Holmvatnet Group makes the contact easy to follow in the field. Despite this, the exact nature of the contact between the two groups has never before been documented and characterised. In the study area, where sandstones dip predominantly to the SE along the contact, previous authors have interpreted the two groups as separated by a subvertical dip-slip fault (Reitan, 1963; Pharaoh et al., 1983; Stribrny, 1985). Although the contact is locally sheared, new mapping reveals two important structural constraints regarding the deformation recorded therein: 1) Observed faults and shear zones are slightly oblique to the actual lithological contact and thus do not separate the two groups other than locally, and 2) None of the observed shear zones has accommodated significant vertical displacement.

The only notable structure observed in proximity to the Saltvatnet-Holmvatnet contact is a subvertical, NE-SWstriking, $\sim 50 \mathrm{~m}$-wide anastomosing shear zone, the Skifergangen shear zone (Viola et al., 2008; Smeplass, 2013). It is best observed within the Magerfellet Formation about $100 \mathrm{~m}$ from the Saltvatnet-Holmvatnet contact where it deforms mainly massive and amygdaloidal basalts (Fig. $2 \mathrm{~A}$ ). Because it is slightly oblique to the lithological contact, it is interpreted to continue into the Ulveryggen Formation to the northeast (Fig. 2A). The Skifergangen shear zone is characterised by a green phyllonite (Fig. 8A) with fine-grained chlorite, biotite and muscovite defining the shear surfaces that wrap around epidote, K-feldspar and quartz porphyroclasts. Subhorizontal mineral stretching lineations on the phyllonitic foliation planes (Fig. 8A) invariably indicate strike-slip kinematics. A penetrative extensional crenulation cleavage fabric (ECC) indicates a dextral sense of shear (Fig. 8A). This is consistent with a slight bending of the regional tectonic foliation into parallelism with the shear zone phyllonitic foliation, as shown by detailed structural mapping of the shear zone (Figs. 2A \& 8A). Microstructural observations by Smeplass (2013) confirm low greenschist-facies conditions during deformation, and support the tectonic model initially proposed by Viola et al. (2008) and subsequently refined by Torgersen et al. (2015), suggesting that this part of the RTW deformed as part of a dextral transpressive shear belt during its structural evolution. The strike-slip kinematic framework of the Skifergangen shear zone and the lack of any sign of structural reactivation demonstrate that the contact has not accommodated any significant vertical displacement. A similar structural framework as the Skifergangen shear zone is observed also for other shear zones, for instance at the Ulveryggen $\mathrm{Cu}$-deposits as described by Stribrny (1985) and Sandstad et al. (2007). Neither the Ulveryggen Formation nor the Magerfjellet Formation show any significant increase in deformation towards the Saltvatnet-Holmvatnet contact (Smeplass, 2013). In the Magerfjellet Formation, for instance, well preserved, undeformed amygdaloidal lavas (Fig. 8B) and, in places, pillow lavas are observed only metres away from the contact to the Ulveryggen Formation (Smeplass, 2013).

We could only observe directly the contact at two localities. Not far from the Skifergangen shear zone, dark green, fine-grained, equigranular mafic lavas rest directly on top of pale greenish-grey arkosic sandstones along a discrete contact dipping steeply to the southeast (145/77; Fig. 8C). Cross-bedding in the underlying sandstones excludes overturning of the sequence.

At another locality north of Holmvatnet (Fig. 2A), the contact is exposed in a west-facing hill slope (Fig. 8D). The contact dips moderately to the southeast $(167 / 25)$ and separates fine-grained, generally massive, mafic lavas (Magerfellet Formation) above from grey-green, medium-grained sandstones (Ulveryggen Formation) below (Fig. 8E). This locality is particularly important because it is where Pharaoh et al. (1983) described their best evidence for placing the Holmvatnet Group at the base of the stratigraphy. These contrasting observations are elaborated further in the discussion section. 

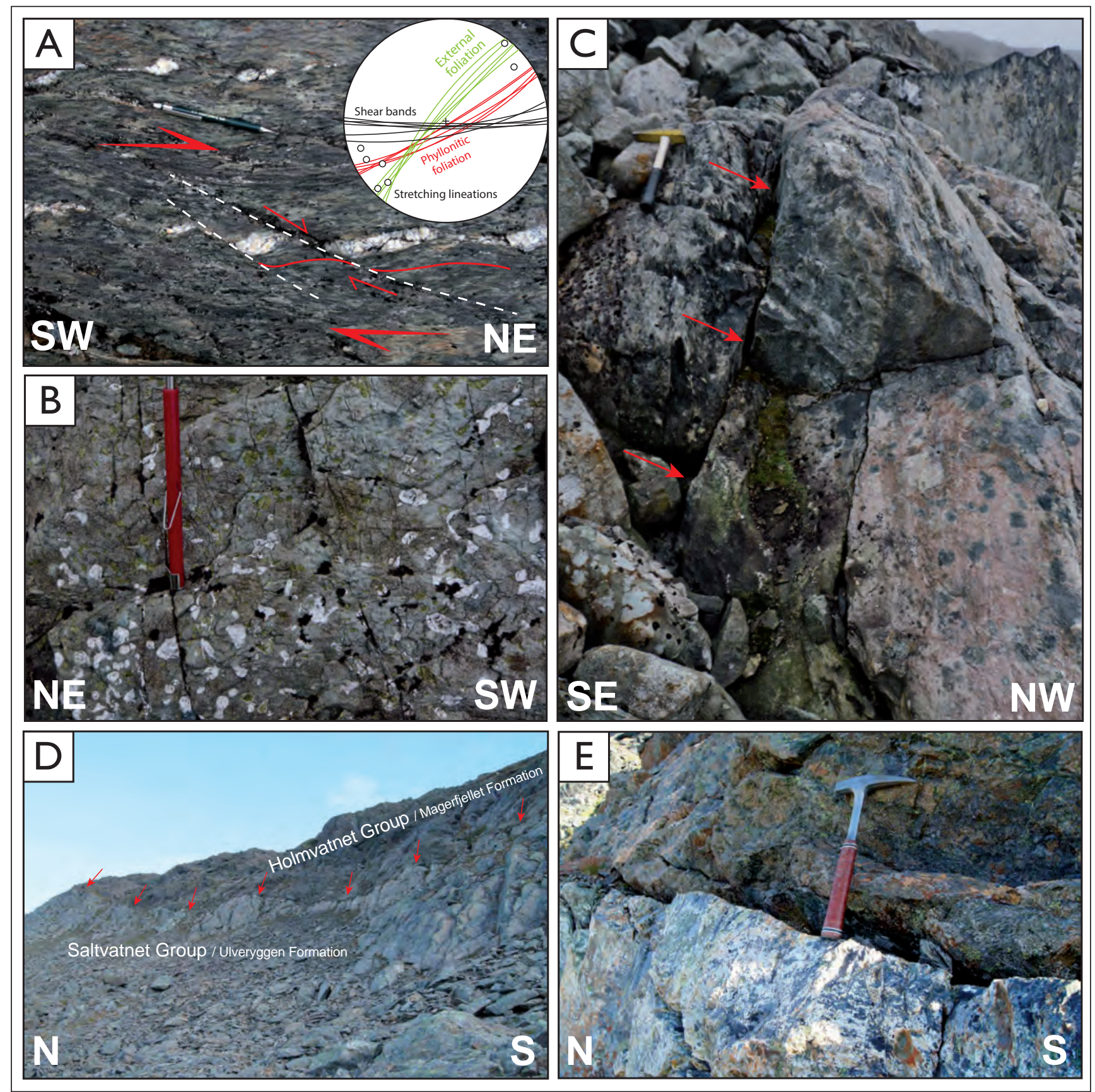

Figure 8. Structural and primary features of rocks along the Saltvatnet-Holmvatnet contact. (A) Dark green, subvertical, NE-SW-striking phyllonite of the Skifergangen shear zone. Shear bands give a dextral sense of shear (619274E/7815151N). Inset stereonet: Lower-hemisphere projection of phyllonitic foliation, shear bands, foliation in the basalts not deformed by the shear zone (external foliation) and stretching lineations. (B) Undeformed amygdaloidal lava a few metres above the contact to Ulveryggen Formation sandstones. Quartz forms most of the amygdales, but some have a core of epidote. (C) Steeply SE-dipping contact between bedded arkosic sandstones to the northwest and massive to amygdaloidal basaltic lavas to the southeast (617849E/7814556N). (D) Moderately SE-dipping contact between basaltic lavas of the Holmvatnet Group above and arkosic sandstones of the Saltvatnet Group below (607201E/7810603N). (E) Close-up of the contact showing notably silicified sandstones below massive, fine-grained basaltic lavas.

\section{Analytical methods}

Major and trace elements in nine igneous rock samples from the RTW (Fig. 2A) were analysed at the Geological Survey of Norway (NGU), Trondheim. Major and trace elements were analysed using a PANalytical Axios $4 \mathrm{~kW}$
X-ray spectrometer, whereas rare earth elements (plus a few additional trace elements) were analysed by LAICP-MS using a Thermo Fisher Scientific 'ELEMENT XR' equipped with a New Wave $193 \mathrm{~nm}$ laser. All analyses where carried out on lithium tetraborate glass beads. The precision $(1 \sigma)$ is typically around $2 \%$ of the major oxide. 


\section{Whole-rock geochemistry of the Nussir Group and Ulveryggen intrusions}

Five of the six analysed samples (HJK_28 to 33; Table 1) are from a sampling profile in the mafic lavas and tuffs of the Nussir Group that extends from the base of the Krokvatnet Formation to the overlying massive lavas of the Svartfjellet Formation (Fig. 2A). Although the Krokvatnet Formation is dominated by tuffs and tuffites, sampling was restricted to interstratified massive to pillowed lava units. The last Nussir Group sample is from the northwesternmost part of the window and represents fine-grained massive lavas of the Svartfjellet Formation (Fig. 2A). All analysed samples from the Nussir Group are green to dark green, fine-grained and massive with rare quartz veinlets.
Three samples from three individual bodies of the Ulveryggen intrusions were analysed to test for any geochemical similarities with the volcanic-dominated Nussir and Holmvatnet Groups. The Ulveryggen intrusions are thin (10-50 m wide), elongated (up to $2 \mathrm{~km} \mathrm{long)} \mathrm{and}$ oriented subconcordantly to the bedding (NE-SW; Fig. 2A). They locally cut the bedding at a very low angle, but it is currently not possible to determine whether they intruded as dykes or sills. All analysed samples represent massive, medium-grained gabbroic rocks that are variably but generally little deformed.

The whole-rock major and trace element data from the Nussir Group and the Ulveryggen intrusions are presented in Table 1 and Fig. 9. All analysed rock samples are tholeiitic basalts with moderate $\mathrm{MgO}, \mathrm{TiO}, \mathrm{Ni}$ and $\mathrm{Cr}$ contents. The Nussir Group volcanic rocks differ, however, from the Ulveryggen intrusions in their trace element

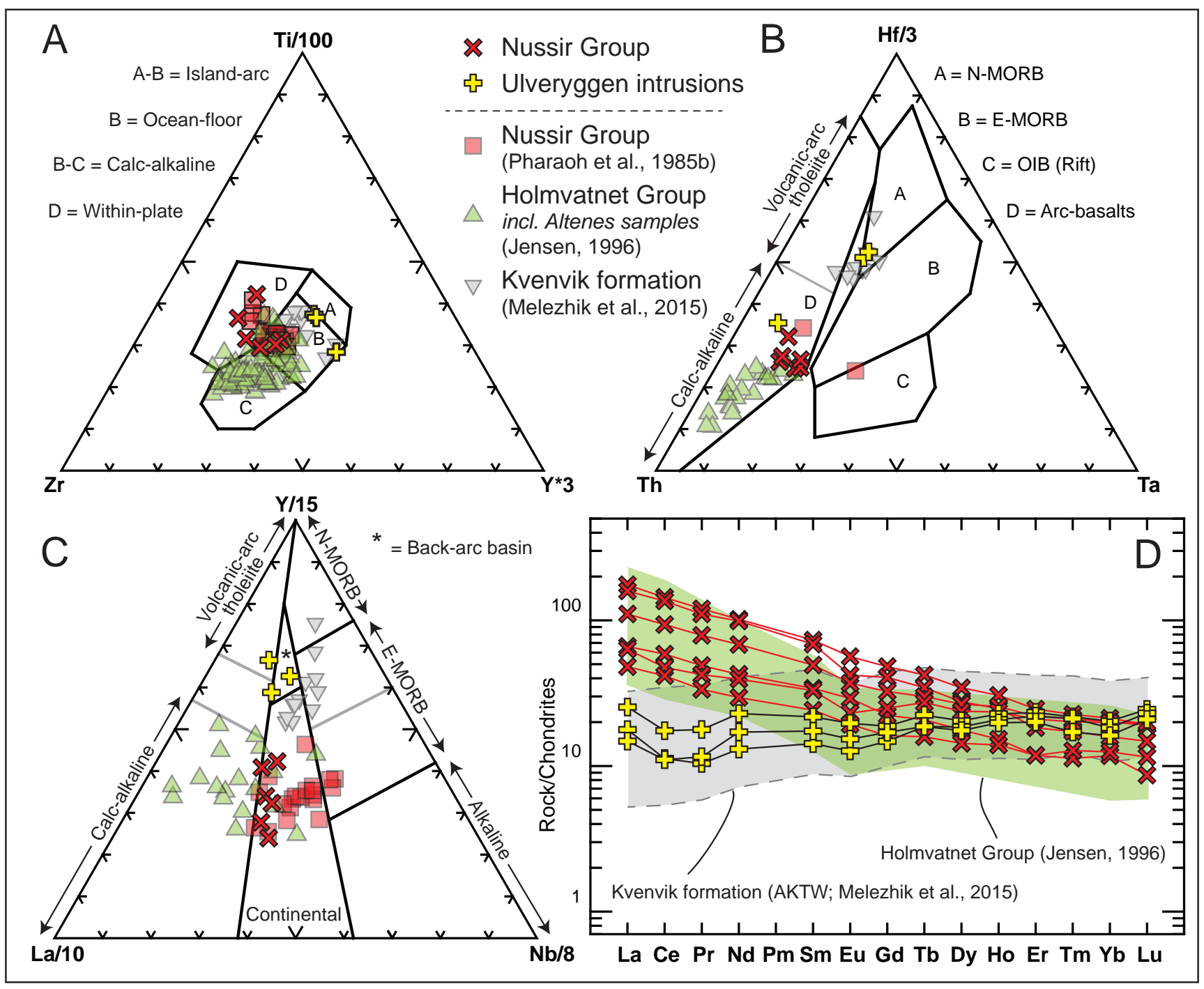

Figure 9. Geochemical signature of igneous rocks of the Nussir Group (red) and Ulveryggen intrusions (yellow). Existing data from the Nussir Group (red squares; Pharaoh, 1985b), Holmvatnet Group (green triangles; Jensen, 1996) and Kvenvik formation (grey triangles; Melezhik et al., 2015) plotted with transparency for ease of comparison. AKTW - Alta-Kvonangen Tectonic Window. (A) A Ti-Zr-Y diagram from Pearce \& Cann (1973). (B) A Th-Hf-Ta diagram from Wood (1980). (C) A Y-La-Nb diagram from Cabanis \& Lecolle (1989) . (D) A REE diagram with chondrite-normalised values from Sun \& McDonough (1989). 


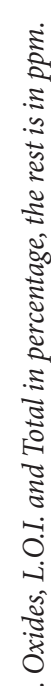

定

हี

3

:

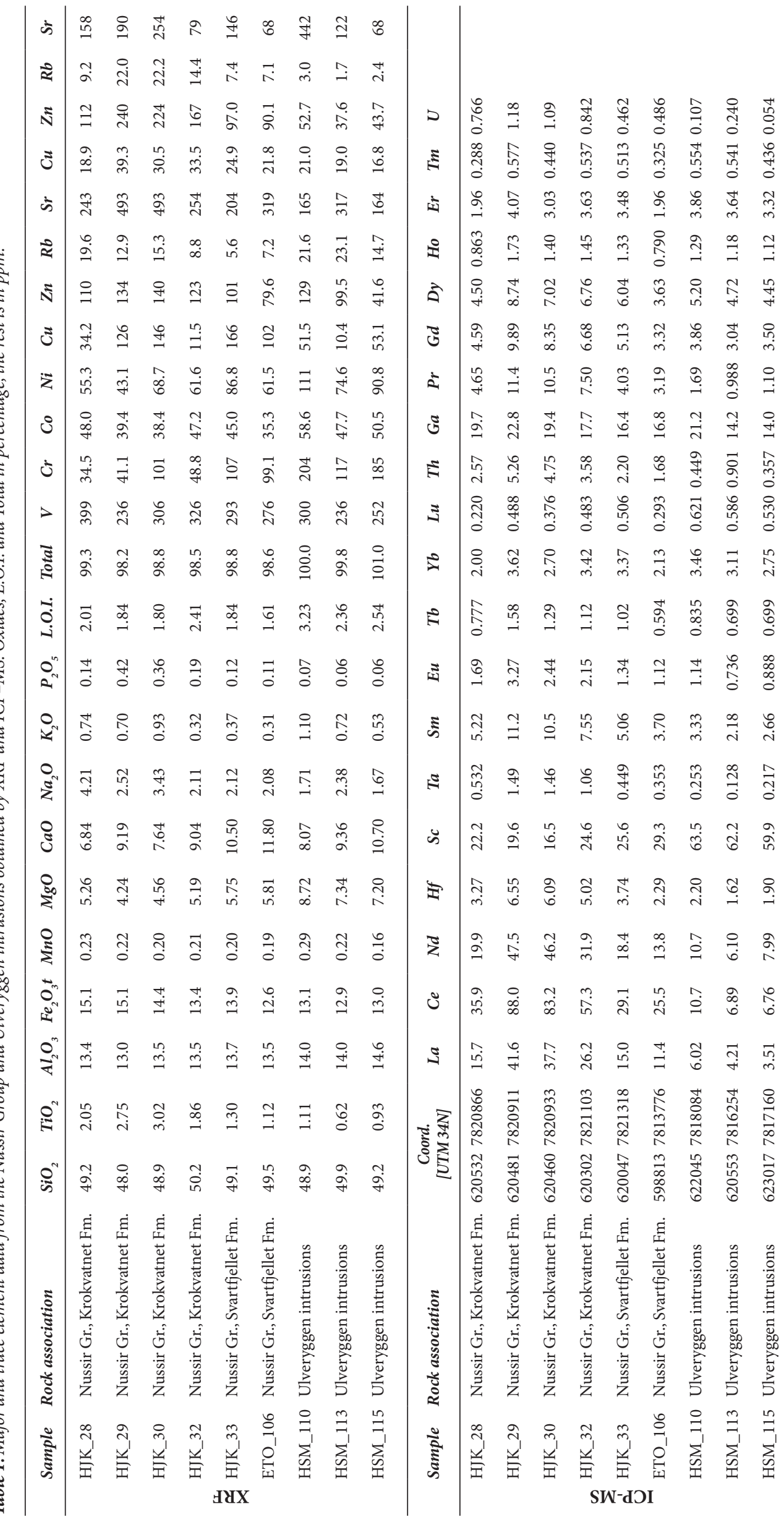


composition. On a classical Ti-Zr-Y discrimination diagram, the Ulveryggen intrusions are transitional ocean-floor / island-arc basalts, whereas the Nussir Group plots across the border between the within-plate and ocean-floor fields (Fig. 9A). In other discrimination diagrams the Nussir Group samples plot as calc-alkaline and continental to calc-alkaline (Fig. 9B, C, respectively), and have a negatively sloped chondrite-normalised rare earth element (REE) pattern (Fig. 9D). The relative enrichment in light REE and large-ion lithophile elements (LILE), such as Th, points toward a significant component of crustal interaction for the parental magmas. The new data on the Nussir Group conform well with existing data from the same group (Fig. 9; Pharaoh, 1985b). Fig. 9 shows that the composition of the Nussir Group basaltic rocks largely overlaps with the composition of the basaltic lavas from the Holmvatnet Group (Jensen, 1996). Although the latter also contains more evolved igneous rocks with a stronger calc-alkaline character (Fig. 9A) and a moderately negative Eu anomaly (Fig. 9D), it is not possible to confidently separate the two groups based solely on their geochemical character.

The Ulveryggen intrusions generally plot closer to the N-MORB field (Fig. 9B, C) and have a flat REE pattern (Fig. 9D), and thus differ significantly from the two volcanic-dominated groups. Instead, these intrusions are compositionally similar to the tholeiitic basalts of the Kvenvik formation in the neighbouring Alta-Kvænangen Tectonic Window (Figs. 1A and 9;; Melezhik et al., 2015).

\section{Discussion}

\section{Existing vs. newly proposed stratigraphy}

Compared to the existing stratigraphy of Pharaoh et al. (1983), we propose two stratigraphic changes: 1) To separate the lower portion of the Krokvatnet Formation/ Nussir Group into a new formation, the Gorahatjohka Formation, belonging to the Saltvatnet Group, and 2) to place the Saltvatnet Group stratigraphically below the Holmvatnet Group. The former is a relatively minor adjustment, but an important clarification, as the existing stratigraphy does not account for the volcaniclastic siltstones and dolostones that host the large Nussir $\mathrm{Cu}-$ (and Ag-) deposit. The latter change has more profound consequences for the understanding of the evolution of the RTW, and it is therefore relevant to review the arguments for the original interpretation and discuss them in the light of the new observations.

Reitan (1963), who defined a preliminary stratigraphic column for the RTW, could not constrain the relative age of the Holmvatnet and Saltvatnet Groups because of the lack of direct field observations. In two of his geological sections (Reitan, 1963, Fig. 13), the Saltvatnet Group is drawn as a large-scale antiform similar to our Ulveryggen anticline, with bedding dipping towards the Holmvatnet Group in the southeast. However, the two groups are separated by a vertical fault in both sections. Reitan (1963) used the lithological resemblance between clasts in the Dypelva Formation and the volcanic and volcaniclastic rocks in the Holmvatnet Group to suggest that the clasts could have been derived from the Holmvatnet Group, which in his view meant that the entire Saltvatnet Group must be the younger.

Although the clasts could have been derived from a completely different mafic volcanic suite that is not exposed today, the lithological similarities between the Holmvatnet Group volcanic rocks and the clasts in the Dypelva Formation are conspicuous. The same applies to the petrographical similarity between the porphyritic dacite clasts in the Stangvatnet Formation and some of the dacitic volcanic rocks in the Holmvatnet Group, which Jensen (1996) in places observed to be porphyritic. If the clasts in the Dypelva and Stangvatnet formations are indeed derived from the Holmvatnet Group, that does not, however, require the whole Saltvatnet Group to be younger than the Holmvatnet Group, as inferred by Reitan (1963). In an active volcanic setting it is not uncommon for alluvial fans to develop from detritus derived predominantly from nearby active volcanic centres (e.g., Chough \& Sohn, 2010). In this case, the Dypelva and Stangvatnet formations could be temporal correlatives of the volcanic rocks (possibly the Holmvatnet Group) that sourced the clasts. This model would also explain why the underlying Ulveryggen Formation contains very little or no volcanic-derived detritus, as volcanic activity had not commenced in the area at the time of its deposition.

The main evidence of Pharaoh et al. (1983) for placing the Saltvatnet Group above the Holmvatnet Group comes from an area north of Holmvatnet (red square in Fig. 2A) where cross-bedding in the Saltvatnet Group is observed to young away from the primary depositional contact. Thus, according to Pharaoh et al. (1983, p. 9), this observation clearly demonstrates that the Holmvatn Group is the older of the two units. Although their observations are not documented by field photographs or sketches, structural measurements on their map (Pharaoh et al., 1983, Plate 1) apparently leave little room for alternative interpretations. Intriguingly, our mapping in the western part of this key area provides some of the best direct field evidence for a totally different interpretation, whereby mafic lavas of the Magerfellet Formation are observed directly overlying the Saltvatnet Group along a moderately southeastdipping stratigraphic contact (Fig. 8D, E). Stratigraphic younging criteria recorded both in this area and elsewhere within the Saltvatnet Group show that nowhere is the stratigraphy overturned, which excludes the possibility for the observed contact (Fig. 8D, E) to be overturned.

The discrepancy between our observations and those of Pharaoh et al. (1983) could possibly be due to the relatively 
abundant mesoscale upright folds close to the SaltvatnetHolmvatnet contact. If the observations of Pharaoh et al. (1983) were made on fold limbs dipping away from the contact, an apparent stratigraphy younging away from it would be inferred. In any case, when combining all our observations made along the Saltvatnet-Holmvatnet contact and the overall geometry of the Ulveryggen anticline (Figs. 4-8), we see no other possibilities than to reject the stratigraphic interpretations made by Pharaoh et al. (1983) in favour of the observations provided herein and the proposed stratigraphic revision, with the Saltvatnet Group below the Holmvatnet Group.

Geochemical data from the Ulveryggen intrusions add further support to the proposed stratigraphic order (Fig. 9). The Ulveryggen intrusions have previously been assigned to the Rødfjellet suite, but the new geochemical data show that their trace-element compositions are different. 'Typical' Rødfjellet suite gabbros and peridotites that intrude the Holmvatnet Group have relatively similar geochemical signatures to the volcanic rocks of the Holmvatnet and Nussir groups (e.g., relative enrichment in LILE and LREE; Pharaoh, 1980; L.P. Nilsson, pers. comm., 2014). Furthermore, out of several hundred geochemical analyses of volcanic and intrusive rocks within the Holmvatnet and Nussir groups, none have the same geochemical character as the Ulveryggen intrusions (Nilsson \& Juve, 1979; Pharaoh, 1980, 1985b; Pharaoh \& Pearce, 1984;; Jensen, 1996; L.P.Nilsson, pers. comm., 2014). Although, in theory, the Ulveryggen intrusions could have been preferentially emplaced in the Ulveryggen Formation well after all sedimentary and volcanic rocks had been deposited, the remarkable lack of these igneous bodies outside of the formation indicates, in our opinion, that they intruded prior to the deposition of the Holmvatnet and Nussir groups. Interestingly, the Ulveryggen intrusions are geochemically identical to the tholeiitic basalts of the Kvenvik formation in the Alta-Kvænangen Tectonic Window south of RTW (Figs. 1A \& 9; Melezhik et al., 2015). Recent radiometric dating has demonstrated that the Kvenvik formation is about 50-100 mill. yr older than the Nussir Group (Melezhik et al., 2015; Perelló et al., 2015; Torgersen et al., 2015). Moreover, the fact that the Ulveryggen intrusions are concordant to subconcordant with the sandstone bedding could indicate that they intruded mainly as sills, and prior to the development of the Ulveryggen anticline. This geometric relationship remains to be tested in the field. In any case, their exclusive presence in the Ulveryggen Formation and their geochemical signature support the interpretation of the Ulveryggen Formation as the lowermost exposed level in the RTW.

\section{Implications of the proposed stratigraphy for local stratigraphic correlations}

A fundamental implication of the proposed stratigraphy is that the Holmvatnet Group, which overlies the Saltvatnet Group on the southeastern limb of the Ulveryggen anticline
(Figs. 2A \& 6), is approximately at the same stratigraphic level of the Nussir Group situated on the other limb (Fig. 3). A direct correlation of the Nussir and Holmvatnet groups may at first seem to be in conflict with firstorder lithological and compositional differences between the two groups, wherein the former comprises mainly tholeiitic basaltic lavas and tuffs, and the latter is more diverse and consists of tholeiitic to calc-alkaline basaltic, andesitic and rhyolitic lavas, tuffs and tuffites. Particularly the partly calc-alkaline character of the Holmvatnet Group has previously been used to distinguish it from the Nussir Group (e.g., Pharaoh \& Pearce, 1984; Pharaoh et al., 1987). Calc-alkaline rocks are, however, confined to the central parts of the group (i.e., Markfjellet and Batdalselv formations), with the exterior part of the group (the Magerfjellet Formation) being composed of tholeiitic basaltic pillow and amygdaloidal lavas and tuffs, just as the Nussir Group (Fig. 2A). Pharaoh (1980) commented on the lithological and petrographical similarities between the Magerfjellet Formation and the Nussir Group, and also noted that they are geochemically comparable, with "trends of evolution [that] are closely similar and parallel" (page 106). In addition, both units contain numerous $\mathrm{Cu}-$ rich carbonate veins with identical mineral assemblages and structural characteristics (Torgersen et al., 2015), which are absent or very scarce elsewhere.

In this sense, the lithological and geochemical differences between the Holmvatnet and Nussir groups are not bigger than the differences within the Holmvatnet Group itself. This could possibly signify that the central and exterior parts of the Holmvatnet Group are either tectonically juxtaposed or represent different, unrelated, magmatic systems. However, an internal tectonic contact has never been documented, and both Pharaoh \& Brewer (1990) and Jensen (1996) have shown that the entire Holmvatnet Group has very similar trace-element geochemical patterns and interpreted it to have differentiated from the same magma. Taking this into account, and given the similarities between the Nussir Group and the Magerfjellet Formation, a correlation of the two groups therefore appears to be feasible. This is, in addition, strengthened by the new geochemical data on the Nussir Group (Fig. 9).

In summary, a correlation of the Holmvatnet and Nussir group, as requested by the revised stratigraphy proposed herein, is supported by their comparable geochemical signature, as well as by the close resemblance between the Nussir Group and the Magerfjellet Formation. The lithological and compositional differences that do exist between the two groups and within the Holmvatnet Group are interpreted as lateral and temporal facies variations during the development of the volcanic system.

A straightforward temporal correlation of the two volcanic groups, however, is challenged by the fact that the Nussir Group is separated from the Ulveryggen Formation by a relatively thick sequence of volcaniclastic 
sedimentary rocks (the Dypelva, Stangvatnet and Gorahatjohka formations) that is in fact absent beneath the Holmvatnet Group. Since no major depositional or tectonic discontinuities have been identified within the Saltvatnet Group, this stratigraphic discrepancy should reflect a primary depositional control. Using the constraints dictated by the geometry of the Ulveryggen anticline and assuming that the contact between the Ulveryggen and Dypelva formations is parallel to the bedding, the sequence of volcaniclastic sedimentary rocks exposed along the northwestern limb should crop out also in the middle part of the currently exposed belt of sandstones, close to the hinge zone of the Ulveryggen anticline (see cross-sections in Fig. 6). Since this is not the case, and because the volcaniclastic succession is not observed anywhere southeast of the axial trace of the Ulveryggen anticline, we propose that the sequence thins drastically to the southeast.

From a geometric viewpoint, such an interpretation is compatible with the significant along-strike thickening of the Dypelva, Stangvatnet and Gorahatjohka formations towards the Skinnfjellet fault zone in the northwest (Fig. 2). Pharaoh et al. (1983) interpreted this thickness variation as a consequence of deformation, with thickening in the hinge of the $\mathrm{km}$-scale, open Nussir syncline, and attenuation along its limbs (Fig. 2A). The lower part of the Dypelva Formation conglomerates can, in places, be intensively foliated and contain strongly flattened clasts (Fig. 4C), but the other formations are generally undeformed (Fig. 4D). The lack of a consistent difference in deformation between the hinge and limbs thus points to a primary origin for the thickness variation. This is confirmed by the geophysical data (Fig. 2B, C), wherein particularly the onlap in the Dypelva Formation of individual conglomerate units with slightly different magnetic properties testifies to a primary increase in thickness towards the northwest (Fig. 2B).

From a sedimentological perspective, the dramatic lateral thickening of these formations is compatible with the commonly short lateral extent of alluvial fan systems (e.g., Bull, 1972). We suggest that the volcaniclastic sequence of the RTW was deposited in a rapidly subsiding basin, as shown by the apparently fast transgression documented by the transition from alluvial-fan deposits via dolostones and siltstones to fine-grained turbidities (Figs. $2 \& 3$ ). The presence of a subaqueous debris flow in the Gorahatjohka Formation (Upper Dolostone Member; Fig. 7E, F), which is suggested to reflect significant gravitational instabilities (see previous section), also points toward a rapidly sinking basin.

In order to accommodate a rapid subsidence, basin development must have been controlled by effective differential displacement along roughly NE-SW-striking syndepositional growth faults, with the master fault located close to the current exposure of the Skinnfjellet fault zone and with increasing throw along strike to the southwest. A half-graben geometry of the basin is indicated by both the thickness variations of the volcaniclastic conglomerates and siltstones, and by the onlap of the conglomerate sequences of the Dypelva conglomerates (Fig. 2B) and of the Lower Dolostone Member in the Gorahatjohka Formation over the underlying Stangvatnet Formation conglomerates (Fig. 2A). It is further substantiated by the mesoscale normal faults observed in the Gorahatjohka Formation (Fig. 5A).

In summary, we propose that the lack of the Dypelva, Stangvatnet and Gorahatjohka formations beneath the Holmvatnet Group on the southeastern limb of the Ulveryggen anticline is due to the spatially heterogeneous and temporally transient deposition of these sediments. Sedimentation appears to have been confined only to the northwestern part of a NE-SW-trending half-graben where a larger accommodation space could facilitate deposition (and preservation).

\section{Tectonic setting and regional correlations}

The evolution of the Fennoscandian Shield in the Early Palaeoproterozoic is known to have been dominated by multiple intracratonic rifting episodes and the development of short-lived oceanic domains (Melezhik \& Sturt, 1994; Melezhik \& Hanski, 2013a). This is reflected by the numerous and voluminous greenstone belts of this age that extend all the way from Russia to northern Norway (Fig. 1A). For example, the AltaKvænangen Tectonic Window, which is situated about 25 $\mathrm{km}$ southwest of the RTW (Fig. 1A), comprises volcanic and sedimentary rocks with geochemical, petrological and sedimentological properties typical of an intraplate rift environment (Melezhik et al., 2015). The Kautokeino Greenstone Belt is also currently best interpreted as an inverted sedimentary basin formed in an intraplate rift (e.g., Olesen \& Sandstad, 1993; Torske \& Bergh, 2004; Henderson et al., 2015).

The overall characteristics of the Repparfjord volcanosedimentary succession are, however, at odds with a solely intracratonic extensional setting. In our opinion, the only convincing evidence for a typical rift setting of the Repparford volcano-sedimentary succession is the dominant continental-derived sediments of the Ulveryggen Formation (arkosic to quartzitic sandstones and conglomerates) and the geochemical signature of the Ulveryggen intrusions. These rocks could possibly represent correlatives of the Masi quartzites and the albite diabase sills in the Kautokeino Greenstone Belt (Fig. 1A; Solli, 1983), the latter of which were emplaced at $2220 \pm$ $7 \mathrm{Ma}$ (Bingen et al., 2015). The Ulveryggen Formation and intrusions form the lowermost part of the proposed stratigraphy of the RTW, but their characteristics diverge significantly from those of the overlying succession, which instead point toward a convergent margin setting. 
Indeed, there is convincing and varied evidence of significant compression broadly associated with subduction during the local geological history. The geochemical character of the volcanic-dominated Holmvatnet and Nussir groups are distinctly different from the within-plate to MORB-type volcanic rocks of similar age present elsewhere in the Palaeoproterozoic domain of northern Norway. The Nussir Group, for instance, has classically been correlated with the Kvenvik formation in the Alta-Kvænangen Tectonic Window, but the new geochemical data show that these differ significantly (Fig. 9). Moreover, a correlation is made problematic by the 50-100 mill. yr. age difference between the two units as recently documented by Melezhik et al. (2015), Perelló et al. (2015) and Torgersen et al. (2015).

The tholeiitic to calc-alkaline affinities and enrichments in LILE and LREE of volcanic rocks in the Holmvatnet and Nussir groups indicate significant crustal interaction of their parental magmas, which can be related to either supra-subduction melting or extensive crustal assimilation in an attenuated continental lithosphere (e.g., Pearce, 1996). Both Pharaoh \& Pearce (1984) and Pharaoh \& Brewer (1990) argued that the geochemical signature of particularly the central parts of the Holmvatnet Group (strong enrichment in Th and moderate enrichment in Ce relative to $\mathrm{Nb}$ ) is indicative of a volcanic arc or back-arc setting. The new data confirm that the Nussir Group lavas have the same signatures as the Holmvatnet Group (Fig. 9). High-Mg, boninite-like metavolcanic rocks within the Holmvatnet Group also suggest a subduction-influenced tectonic setting (Jensen, 1996). At the same time, though, it may also be argued that the distinctive geochemical characteristics of the RTW succession simply reflect its development in an intracratonic rift with a more significant component of crustal melting than elsewhere.

The interpretation of tectonic setting based solely on geochemical evidence is generally not straightforward and unambiguous, and should be coupled with other observations. This is not only because of the intrinsic difficulty of geochemically separating rifting within an attenuated continental lithosphere from that in a back-arc (e.g., Pearce, 1996), but also because Early Palaeoproterozoic crust and mantle dynamics, and consequently style of orogenesis, were most likely different from today (e.g., Roberts et al., 2015). In any case, there are other geological aspects of the RTW succession that support a transient compressional tectonic setting during its evolution.

The most compelling evidence of compression comes from the abundant $\mathrm{Cu}$-rich carbonate veins that are found particularly within the Nussir Group and the Magerfjellet Formation. Structural analysis constrains the formation and deformation of these veins during overall NW-SE compression, which is dated at $2069 \pm$ $14 \mathrm{Ma}$ by $\mathrm{Re}-\mathrm{Os}$ sulphide geochronology (Torgersen et al., 2015). These veins therefore attest to a phase of roughly NW-SE shortening that predates by about 100 mill. yr the peak of Svecofennian compression elsewhere on the Fennoscandian Shield (e.g., Lahtinen et al., 2008). The occurrence of this early compressional phase in a time interval dominated by extension in most of the Fennoscandian Shield (Melezhik \& Hanski, 2013b), lends further support to an overall convergent margin setting as the first-order geodynamic scenario for the RTW. Compression and extension may have affected transiently and repeatedly large areas in response to the regional geodynamic framework, possibly characterised by subduction, collision and broadly coeval slab roll-back.

Indirect evidence of an overall convergent margin setting is provided by the voluminous record of volcaniclastic rocks within the RTW, which are not documented elsewhere in the Palaeoproterozoic domain of northern Norway. The Dypelva, Stangvatnet and Gorahatjohka formations represent thick packages of volcaniclastic sediments that, as discussed above, reflect the deposition of locally derived volcanic material in a rapidly subsiding basin. Also, the Holmvatnet Group hosts abundant volcanogenic sediments such as tuffs, tuffites and pyroclastic flow deposits, in addition to the volcanic rocks (Pharaoh et al., 1983; Jensen, 1996; Nilsen \& Nilsson, 1996). The documented thick volcaniclastic deposits, high sedimentation rates, turbidite deposits and calc-alkaline volcanic rocks in the RTW present many similarities with conditions observed in modern magmatic arcs (Jensen, 1996).

We propose that the Repparfjord volcano-sedimentary succession reflects either the progressive development of an arc / back-arc system or the inversion of an initial intracratonic rift in a subsequent compressional tectonic setting (see Henderson et al., 2015). The timing of this overall convergent tectonic regime is in any case constrained by the $\sim 2070 \mathrm{Ma}$ age of the volcanic rocks and carbonate veins (Perelló et al., 2015; Torgersen et al., 2015). Rocks of similar age and genetically linked to a similar tectonic setting are very scarce on the Fennoscandian Shield. The only exception documented so far on the Fennoscandian Shield is that of the metavolcanic and metasedimentary rocks of the Porphyrite and Kiirunavaara groups in Norrbotten, northern Sweden (Fig. 1A). These formed at around $2050 \mathrm{Ma}$ or earlier (Storey et al., 2007) and are interpreted to relate either to early arc formation or to bimodal magmatism (Martinsson, 2004; Smith et al., 2009). Volcanic rocks of a similar age are also present in the Kittilä greenstones of the Central Lapland Greenstone Belt (2.0-2.06 Ga metadiabases and gabbros; Rastas et al., 2001) and in the Peräpohja Schist Belt (approximately 2.05 Ga felsic porphyry; Fig. 1A; Perttunen \& Vaasjoki, 2001), but these are supposedly not associated with a convergent tectonic setting. 


\section{The Early Palaeoproterozoic evolution of the} Repparfjord volcano-sedimentary succession

Fig. 10 presents a conceptual scheme for the Early Palaeoproterozoic evolution of the RTW. The revised stratigraphy of the volcano-sedimentary succession is suggested to reflect the gradual development of a halfgraben basin that eventually rifted and evolved into a shallow-marine shelf area. As discussed in the previous section, available data indicate that most of the Repparford volcano-sedimentary succession formed in an overall collisional tectonic setting, possibly a continental backarc (Fig. 10). The interpreted distribution of basin- and arc-related sedimentary and volcanic rocks indicates a northwestward subduction underneath the RTW in present-day coordinates, wherein the extension recorded in the window was possibly caused by a rollback of the subducting slab (Fig. 10A, B)

According to our revised stratigraphy, the oldest exposed rocks in the northern part of the RTW are the arkosic sandstones of the Ulveryggen Formation, which were deposited in braided river systems, possibly unconformably on top of an Archaean basement. Limited paleocurrent studies indicate that these sediments were largely supplied from the W-NW (Pharaoh, 1980). The depositional age of the sandstones is not yet well constrained, but a minimum age is provided by the 2073 $+23 /-12 \mathrm{Ma}$ age of the overlying Nussir Group (Perelló et al., 2015). The Ulveryggen intrusions were emplaced mainly as sills, most likely during or soon after sediment deposition. Their geochemical characteristics point toward an intraplate rift setting at this time (Fig. 9).

The thick and laterally limited alluvial-fan deposits demonstrate that significant relief started to develop to the northwest of the currently exposed belt of arkosic sandstones (Fig. 10D). We suggest that the uplifted source area for the fan deposit and the accommodation space in the sink were created by displacement along syndepositional, roughly NE-SW-striking, growth normal faults. In the developing NE-SW-trending basins, conglomerates of the Dypelva and Stangvatnet formations were deposited along the basin margins at the same time as the Ulveryggen Formation sandstones were deposited in the axial region by low-energy, basinparallel, braided streams (Fig. 10D). The similarities between the clasts in the conglomerates and the volcanic rocks in the Holmvatnet/Nussir groups could suggest simultaneous volcanic activity in the near vicinity. The upward sedimentological changes from the Dypelva Formation to the Stangvatnet Formation indicate a transition from debris flow-dominated to stream flowdominated alluvial-fan deposits. A further transition into the overlying siltstones, dolarenites, dolobreccia and turbidites of the Gorahatjohka Formation represents the progressive deepening and drowning of the basin from initially shallow-water conditions to deeper-marine conditions (Fig. 10E).
Within the currently exposed part of the RTW, the emplacement of volcanic rocks of the Nussir and Holmvatnet groups followed the deposition of the volcaniclastic siltstones at around $2070 \mathrm{Ma}$ (Fig. 10F, G; Perelló et al., 2015; Torgersen et al., 2015). The lithological and geochemical variations in volcanic and volcaniclastic lithologies are interpreted to reflect lateral facies changes within a continental back-arc system, wherein the tholeiitic basaltic rocks were concentrated towards the locus of actual rifting, whereas the calc-alkaline and generally more evolved lavas were emplaced closer to the rising volcanic arc. The very complex distribution of rocks in the central parts of the Holmvatnet Group (Nilsen \& Nilsson, 1996), comprising numerous interfingered lenses of volcanic and volcaniclastic rocks of various composition, is interpreted to reflect such an arc setting.

Volcanic activity was followed by the formation of abundant Cu-rich carbonate veins at $2069 \pm 14 \mathrm{Ma}$ (Fig. 10G; Torgersen et al., 2015). Their emplacement was associated with a transient phase of roughly NW-SE shortening. This time period was followed by the deposition of relatively shallow-marine dolostones, graphitic shales and tuffites of the Porsa Group (Pharaoh et al., 1983), which have not been discussed in detail herein.

The entire Repparfjord volcano-sedimentary succession was subsequently deformed and metamorphosed at greenschist- to lower amphibolite-facies conditions during the Svecofennian Orogeny at approximately 1900$1840 \mathrm{Ma}$ (Fig. 10I). Overall NW-SE compression caused large-scale upright folding of the succession about NESW-trending axes, as demonstrated by the Ulveryggen anticline, as well as localised dextral strike-slip shearing along NE-SW-striking shear zones. This event was most likely synchronous with the syn-orogenic emplacement of the ultramafic to mafic Rødfjellet suite, which has recently been dated at $1903 \pm 20 \mathrm{Ma}$ (Fig. 10I; Bingen et al., 2015). An Ar-Ar biotite plateau age of $1743 \pm 4$ Ma probably constrains the end of regional metamorphism in this area (Bingen et al., 2015), and is in agreement with a Re-Os age of molybdenite from the $\mathrm{Cu}$-mineralised Middle Dolostone Member of the Gorahatjohka Formation at $\sim 1765 \mathrm{Ma}$ (Perelló et al., 2015).

Implications of the revised structure and stratigraphy for the RTW sediment-hosted Cu-deposits

The Repparfjord volcano-sedimentary succession, and in particular the Saltvatnet Group, has a significant economic dimension as it hosts the large Nussir and Ulveryggen Cu-deposits (66 Mt at $1.15 \% \mathrm{Cu}$ and $7.7 \mathrm{Mt}$ at $0.8 \% \mathrm{Cu}$, respectively; Figs. 2A \& 3B; Nussir ASA, 2015). Although we did not focus specifically on these deposits in this study, it is worth discussing here the implications of the revised structure and stratigraphy on the geological setting of the two mineralisations. 


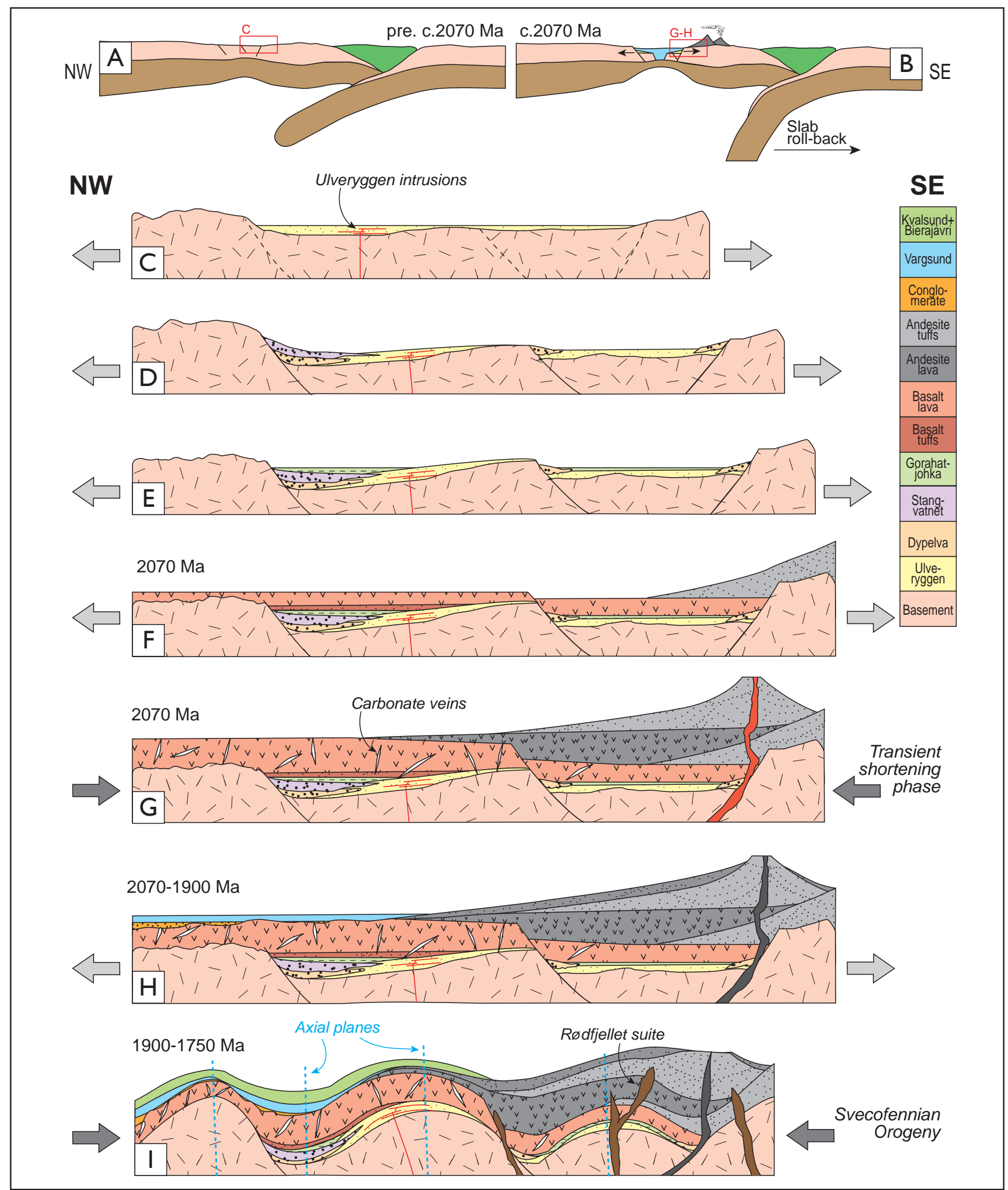

Figure 10. Suggested depositional and tectonic evolution of the Repparfjord volcano-sedimentary succession for the Early Palaeoproterozoic. $(A, B)$ Back-arc setting of the Repparfjord area during $(A)$ the deposition of the Ulveryggen Formation and incipient rifting due to possible slab roll-back pre $\sim 2070 \mathrm{Ma}$ and (B) emplacement of extrusive volcanic and volcaniclastic rocks of the Nussir and Holmvatnet groups at around $2070 \mathrm{Ma}$. (C) Deposition of continental-derived sediments and intrusion of MORB-type basaltic sills (Ulveryggen intrusions). (D) Rifting leading to half-graben basin development and deposition along the margins of thick alluvial fans followed by deposition of volcaniclastic siltstones and dolostones. (E, F) Continued rifting with emplacement of lava flows and tuffs at around $2070 \mathrm{Ma}$. Mafic, tholeiitic rocks would have been extruded predominantly towards the rift locus, whereas more evolved, calc-alkaline rocks dominate the main arc. (G) Transient shorting phase of the back-arc basin caused the formation of mineralised carbonate veins at approximately $2070 \mathrm{Ma}$. (H) Shallow-marine sediments (Porsa Group) were deposited, possibly on the shelf of the back-arc basin, between about 2070 and 1900 Ma. (I) Compression during the Svecofennian orogeny with large-scale upright folds and intrusion of the mafic to ultramafic Rødfjellet suite at c. $1900 \mathrm{Ma}$. Metamorphism ended at around $1750 \mathrm{Ma}$. 
The Nussir and Ulveryggen deposits resemble classical sediment-hosted $\mathrm{Cu}$-deposits such as the Central African Copperbelt and the Central European Kupferschiefer in terms of host-rock assemblage, texture and mineralogy. However, the overall convergent tectonic setting proposed for the Repparford volcano-sedimentary succession differs from the typical intracontinental rift setting inferred for most other sediment-hosted $\mathrm{Cu}$ mineralisations (e.g., Brown, 1992).

The formation of the RTW sediment-hosted Cu-deposits is not yet fully understood and complications are due to the fact that they invariably exhibit coexisting textural features indicative of both syndiagenetic and epigenetic ore-mineral precipitation, in addition to localised structural reworking (Stribrny, 1985; Sandstad et al., 2007, 2012; Nilsen \& Martinsen, 2009; Torgersen et al., 2014a; Perelló et al., 2015). Perelló et al. (2015) argue for an exclusively structurally controlled, synorogenic formation of the RTW sediment-hosted Cu-deposits based on the Re-Os dating of molybdenite $(\sim 1765 \mathrm{Ma})$ associated with the Nussir deposit. Although remobilisation during deformation of the host rock is indeed recorded, the dominant Nussir deposit $\mathrm{Cu}$ sulphides comprise more commonly interstitial grains and aggregates in the dolarenite matrix (Sandstad, 2010). This suggests an initial diagenetic formation of the main $\mathrm{Cu}$ mineralisation, which must have taken place just before and/or during the deposition of the overlying Nussir and Holmvatnet groups (i.e., $\geq 2070$ Ma; Perelló et al., 2015; Torgersen et al., 2015).

Based on the tectonic setting and geological evolution proposed for the RTW, it is convenient to interpret the coexistence of syndiagenetic and epigenetic textural features in the deposits as evidence for progressive precipitation and recrystallisation of ore minerals in a basin that repeatedly experienced transient extensional and compressional tectonic events from around $2070 \mathrm{Ma}$ (Fig. 10). The formation of $\mathrm{Cu}$-rich carbonate veins within the volcanic rocks of the Nussir and Holmvatnet groups at $2069 \pm 14 \mathrm{Ma}$ demonstrates that this time period was associated with significant transport and precipitation of copper (Torgersen et al., 2015).

An additional implication of the proposed structural setting and stratigraphy is that the Holmvatnet Group volcanic rocks can no longer be the source of copper for the Ulveryggen and Nussir deposits, as previously proposed (e.g., Stribrny, 1985). This means that the source rocks may be buried below the Saltvatnet Group and not exposed anywhere within the RTW. Interestingly, very similar sediment-hosted $\mathrm{Cu}$-mineralisations can be traced for several tens of kilomteres in the Alta-Kvænangen Tectonic Window. The age of the host dolostone is there $<2060 \mathrm{Ma}$ and it rests unconformably on the $\geq 80$ mill. yr older Kvenvik formation (Melezhik et al., 2015). Melezhik et al. (op.cit.) suggest that sulphates and halite at the base of the Kvenvik formation were the source for $\mathrm{Cl}-\mathrm{Na}$-rich fluids that caused regional albitisation and scapolitisation, as well as the formation of spatially and genetically linked $\mathrm{Cu}$-deposits (Frietsch et al., 1997). Given that the Kvenvik formation is older than the volcanic rocks exposed in the RTW, a correlative (but not exposed) formation may represent the source rocks that rest beneath the Saltvatnet Group in the RTW.

\section{Conclusions}

By combining new field observations, structural analysis, whole-rock geochemistry and high-resolution geophysical data, this study proposes a revised stratigraphy and structural framework for the $\sim 8 \mathrm{~km}$-thick Early Palaeoproterozoic Repparfjord volcano-sedimentary succession exposed in the RTW. The most important results and implications of the study are:

- The Saltvatnet Group is expanded to comprise four formations, including the uppermost volcaniclastic siltstones and dolostone members of the herein suggested Gorahatjohka Formation, which hosts the large Nussir $\mathrm{Cu}-$ (and Ag-) deposit.

- The volcaniclastic conglomerates (Djupelv and Stangvann formations) and siltstones (Gorahatjohka Formation) of the Saltvatnet Group were deposited in a rapidly subsiding NE-SW-trending half-graben, wherein subsidence was actively controlled by displacement along a SE-dipping syn-sedimentary growth fault.

- The current geometry of the Saltvatnet Group is that of a km-scale, upright, NE-SW-trending anticline, here called the Ulveryggen anticline. This fold geometrically requires the Saltvatnet Group to represent the lowermost exposed rocks in the RTW.

- Detailed mapping and structural analysis demonstrate that the Holmvatnet-Saltvatnet contact is a primary stratigraphic contact that is only locally tectonised and never overturned. Direct observations of the contact confirm that the Saltvatnet Group is situated stratigraphically below the Holmvatnet Group.

- The basaltic lavas of the Nussir Group have similar geochemical characteristics as those of the Holmvatnet Group. With the two groups situated on either limb of the Ulveryggen anticline, we interpret them as temporal and lateral correlatives erupted at around $2070 \mathrm{Ma}$.

- The Ulveryggen intrusions, which intrude the Ulveryggen Formation, are geochemically different from any other igneous rocks in the RTW, suggesting that they were emplaced prior to deposition of the volcanicdominated groups in the RTW. This further supports the model wherein the Saltvatnet Group is the low- 
ermost exposed unit of the window. The Ulveryggen intrusions are geochemically similar to the $\sim 2220$ 2150 Ma Kvenvik Formation in the Alta-Kvænangen Tectonic Window.

- The Repparfjord volcano-sedimentary succession reflects the gradual development and drowning of a halfgraben that eventually rifted and evolved into a shallow-marine shelf. We interpret the tectonic setting to be similar to that of an evolving continental back-arc, with transient extensional and compressional events, which contrasts with the pure intraplate rift setting inferred for most parts of the Fennoscandian Shield in the Early Paleoproterozoic.

- The overall convergent tectonic setting of the sedimenthosted Nussir and Ulveryggen $\mathrm{Cu}$-deposits differs from the typical intracontinental rift setting of similar mineralisations elsewhere. The coexistence of syndiagenetic and epigenetic textural features in the RTW sedimenthosted $\mathrm{Cu}$-deposits can be interpreted as evidence for progressive precipitation and recrystallisation of ore minerals in a basin that repeatedly experienced transient extensional and compressional tectonic events.

Acknowledgements. Hans Jørgen Kjøll and Håvard Smeplass assisted with the mapping of key areas and contributed with structural measurements, samples and photographs during their M.Sc. projects at IGB/ NTNU in Trondheim under Giulio Viola's supervision. Their input is very gratefully acknowledged. Victor Melezhik and Hans Jørgen Kjøll kindly provided their input to an earlier version of the manuscript, and Kjell S. Nilsen is thanked for good discussions on the general geology of the RTW and for suggesting the name Gorahatjohka for the new formation. A constructive review by Torgeir B. Andersen is gratefully acknowledged, and Hugh Rice is thanked for comments on an early version of the manuscript.

\section{References}

Bingen, B., Solli, A., Viola, G., Torgersen, E., Sandstad, J.S., Whitehouse, M.J., Ganerød, M. \& Nasuti, A. 2015: Geochronology of the Palaeoproterozoic Kautokeino Greenstone Belt, Finnmark, northern Norway: Tectonic implications in a Fennoscandia context. Norwegian Journal of Geology 95, 365-396. http://dx.doi. org/10.17850/njg95-3-09.

Brown, A.C. 1992: Sediment-hosted stratiform copper deposits. Geoscience Canada 19, 125-141.

Bull, W.B. 1972: Recognition of Alluvial-Fan Deposits in the Stratigraphic Record: Recognition of Ancient Sedimentary Environments 16, SEPM Society for Sedimentary Geology, 63-83. doi: http://dx.doi.org/10.2110/pec.72.02.0063.

Cabanis, B. \& Lecolle, M. 1989: Le diagramme La/10-Y/15-Nb/8 : un outil pour la discrimination des series volcaniques et la mise en evidence des processus de melande et/ou de contamination crustale. Comptes Rendus de l'Académie des Sciences Series II 309, 2023-2029.

Chough, S.K. \& Sohn, Y.K. 2010: Tectonic and sedimentary evolution of a Cretaceous continental arc-backarc system in the Korean peninsula: New view. Earth-Science Reviews 101, 225-249. doi: http://dx.doi.org/10.1016/j.earscirev.2010.05.004.

Dallmeyer, R.D., Mitchell, J.G., Pharaoh, T.C., Reuter, A. \& Andresen, A. 1988: K-Ar and Ar-40/Ar-39 Whole-Rock Ages of Slate Phyllite from Allochthonous Basement and Cover in the Tectonic Windows of Finnmark, Norway - Evaluating the Extent and Timing of Caledonian Tectonothermal Activity. Geological Society of America Bulletin 100, 1493-1501. doi: http://dx.doi.org/10.1130/00167606(1988) 100<1493:Kaaaaw>2.3.Co;2.

Frietsch, R., Tuisku, P., Martinsson, O. \& Perdahl, J.-A. 1997: Early proterozoic $\mathrm{Cu}-(\mathrm{Au})$ and $\mathrm{Fe}$ ore deposits associated with regional $\mathrm{Na}-\mathrm{Cl}$ metasomatism in northern Fennoscandia. Ore Geology Reviews 12,1-34.

Gayer, R.A., Rice, A.H.N., Roberts, D., Townsend, C. \& Welbon, A. 1987: Restoration of the Caledonian Baltoscandian margin from balanced cross-sections: the problem of excess continental crust. Transactions of the Royal Society of Edinburgh: Earth Sciences 78, 197-217. doi: http://dx.doi.org/10.1017/S026359330001110X.

Gee, D.G., Fossen, H., Henriksen, N. \& Higgins, A.K. 2008: From the early Paleozoic platforms of Baltica and Laurentia to the Caledonide Orogen of Scandinavia and Greenland. Episodes 31, $44-51$.

Heincke, B., Koziel, J., Walker, P. \& Lynum, R. 2008: Helicopter-borne geophysical measurements for mineral exploration at Nussir, Kvalsund commune in Finnmark. Norges geologiske undersøkelse Report 2008.020,32 pp.

Henderson, I.H.C, Viola, G. \& Nasuti, A. 2015: A new tectonic model for the Kautokeino Greenstone Belt, northern Norway, based on high-resolution airborne magnetic data and field structural analysis and implications for mineral potential. Norwegian Journal of Geology 95, 339-363. http://dx.doi.org/10.17850/njg95-3-05.

Jansen, O.J. 1976: Strukturell og metamorf utvikling $i$ den vestlige del av Komagfjord viduet og overliggende dekker. Cand. Real. thesis, Univerisity of Bergen, $198 \mathrm{pp}$.

Jensen, P.A. 1996: The Altenes and Repparfjord tectonic windows, Finnmark, northern Norway. Remnants of a Palaeoproterozoic Andean-type plate margin at the rim of the Baltic Shield. $\mathrm{PhD}$ thesis, University of Tromsø, $120 \mathrm{pp}$.

Kjøll, H.J., Viola, G., Menegon, L. \& Sørensen, B.E. 2015: Brittle-viscous deformation of vein quartz under fluid-rich low greenschist facies conditions. Solid Earth 6, 681-699. doi: http://dx.doi.org/10.5194/ se-6-681-2015.

Koistinen, T., Stephens, M.B., Bogatchev, V., Nordgulen, Ø., Wennerström, M. \& Korhonen, J. 2001: Geological Map of the Fennoscandian Shield, scale 1:2,000,000, Geological Survey of Finland, Norway and Sweden and the North-West Department of Natural resources of Russia.

Lahtinen, R., Garde, A.A. \& Melezhik, V.A. 2008: Paleoproterozoic evolution of Fennoscandia and Greenland. Episodes 31, 20-28.

Martinsson, O. 2004: Geology and Metallogeny of the Northern Norrbotten Fe-Cu-Au Province. In Allen, R., Martinsson, O. \& Weihed, P. (eds.): Svecofennian Ore-Forming Environments Field Trip Volcanic-associated $\mathrm{Zn}-\mathrm{Cu}-\mathrm{Au}-\mathrm{Ag}$ and magnetite-apatite, sediment-hosted $\mathrm{Pb}-\mathrm{Zn}$, and intrusion-associated $\mathrm{Cu}-\mathrm{Au}$ deposits in northern Sweden, Society of Economic Geologists Guidebook Series 33, pp. 131-148.

Melezhik, V.A. \& Sturt, B.A. 1994: General geology and evolutionary history of the early proterozoic Polmak-Pasvik-Pechenga-Imandra/ Varzuga-Ust'Ponoy greenstone belt in the northeastern Baltic Shield. Earth-Science Reviews 36, 205-241. doi: http://dx.doi. org/10.1016/0012-8252(94)90058-2.

Melezhik, V. \& Hanski, E. 2013a: 3.1 The Early Palaeoproterozoic of Fennoscandia: Geological and Tectonic Settings. 4 Melezhik, V.A., Prave, A.R., Hanski, E.J., Fallick, A.E., Lepland, A., Kump, L.R. \& Strauss, H. (eds.): Reading the Archive of Earth's Oxygenation 1, Frontiers in Earth Sciences, Springer, Berlin Heidelberg, pp. 33-38. doi: http://dx.doi.org/10.1007/978-3-642-29682-6_3.

Melezhik, V.A. \& Hanski, E.J. 2013b: 3.3 Palaeotectonic and Palaeogeographic Evolution of Fennoscandia in the Early Palaeoproterozoic. In Melezhik, V.A., Prave, A.R., Fallick, A.E., Kump, L.R., Strauss, H., Lepland, A. \& Hanski, E.J. (eds.): Reading the Archive of Earth's Oxygenation 1, Frontiers in Earth Sciences, 
Springer, Berlin Heidelberg, pp. 111-178. doi: http://dx.doi. org/10.1007/978-3-642-29682-6_5.

Melezhik, V.A., Bingen, B., Sandstad, J.S., Pokrovsky, B.G., Solli, A. \& Fallick, A.E. 2015a: Sedimentary-volcanic successions of the Alta-Kvænangen Tectonic Window in the northern Norwegian Caledonides: Multiple constraints on deposition and correlation with complexes on the Fennoscandian Shield. Norwegian Journal of Geology 95, 245-284. http://dx.doi.org/10.17850/njg95-3-01.

Nilsen, K.S. \& Nilsson, L.P. 1996: Berggrunnskart; Vargsund, scale 1:50 000, Norges geologiske undersøkelse.

Nilsen, K.S. \& Martinsen, M. 2009: Nussir kobbermalm, en sedimentær forekomsttype. Abstracts and Proceedings, Geological Society of Norway Annual Meeting, 13-15 January, Bergen, Norway.

Nilsson, L.P. \& Juve, G. 1979: En kjemisk-mineralogisk undersøkelse av ultramafiske bergarter i Komagfjordvinduet med henblikk på å bestemme eventuelle økonomiske konsentrasjoner av malmmineraler. Norges geologiske undersøkelse Report 1682/1, 75 pp.

Nussir ASA 2015: Official grades from Nussir ASA. http://www.nussir. no/en_projec_nussir.php (accessed 23.03.2015).

Nystuen, J.P.E. 1986: Regler og råd for navnsetting av geologiske enheter i Norge. Av Norsk stratigrafisk komité. Norwegian Journal of Geology 66 (Suppl. 1), 1-96.

Ofstad, F., Baranwal, V., Koziel, J., Lynum, R. \& Rodionov, A. 2013: Helicopter-borne magnetic, electromagnetic and radiometric geophysical survey in Repparfjord area, Alta and Kvalsund, Finnmark. Norges geologiske undersøkelse Report 2013.027, 25 pp.

Olesen, O. \& Sandstad, J.S. 1993: Interpretation of the Proterozoic Kautokeino Greenstone Belt, Finnmark, Norway from combined geophysical and geological data. Norges geologiske undersøkelse Bulletin 425, 41-62.

Pearce, J.A. 1996: A user's guide to basalt discrimination diagrams. In Wyman, D.A. (ed.): Trace element geochemistry of volcanic rocks: applications for massive sulphide exploration, Geological Association of Canada Short Course Notes 12, pp. 79-113.

Pearce, J.A. \& Cann, J.R. 1973: Tectonic setting of basic volcanic rocks determined using trace element analyses. Earth and Planetary Science Letters 19, 290-300. doi: http://dx.doi.org/10.1016/0012821X(73)90129-5.

Perelló, J., Clifford, J.A., Creaser, R.A. \& Valencia, V.A. 2015: An Example of Synorogenic Sediment-Hosted Copper Mineralization: Geologic and Geochronologic Evidence from the Paleoproterozoic Nussir Deposit, Finnmark, Arctic Norway. Economic Geology 110, 677-689. doi: http://dx.doi.org/10.2113/econgeo.110.3.677.

Perttunen, V. \& Vaasjoki, M. 2001: U-Pb geochronology of the Perapohja Schist Belt, northwestern Finland. In Vaasjoki, M. (ed.): Radiometric age determinations from Finnish Lapland and their bearing on the timing of Precambrian volcano-sedimentary sequences, Geological Survey of Finland Special Paper 33, pp. 45-84.

Pharaoh, T.C. 1980: The Geological History of the Komagfjord Tectonic Window, Finnmark, Northern Norway. PhD thesis, University of Dundee, 238 pp.

Pharaoh, T.C. 1985a: The stratigraphy and sedimentology of autochthonous metasediments in the Repparfjord-Komagfjord Tectonic Window, west Finnmark. 4 Gee, D.G. \& Sturt, B.A. (eds.): The Caledonide Orogen - Scandinavia and Related Areas, John Wiley \& Sons Ltd., Chichester, pp. 347-372.

Pharaoh, T.C. 1985b: Volcanic and geochemical stratigraphy of the Nussir Group of Arctic Norway-an early Proterozoic greenstone suite. Journal of the Geological Society 142, 259-278. doi: http:// dx.doi.org/10.1144/gsigs.142.2.0259.

Pharaoh, T.C. \& Pearce, J.A. 1984: Geochemical evidence for the geotectonic setting of early Proterozoic metavolcanic sequences in Lapland. Precambrian Research 25, 283-308. doi: http://dx.doi. org/10.1016/0301-9268(84)90037-8.

Pharaoh, T.C. \& Brewer, T.S. 1990: Spatial and temporal diversity of early Proterozoic volcanic sequences - comparisons between the Baltic and Laurentian shields. Precambrian Research 47, 169-189. doi: http://dx.doi.org/10.1016/0301-9268(90)90037-Q.

Pharaoh, T.C., Macintyre, R.M. \& Ramsay, D.M. 1982: K-Ar age determination on the Raipas suite in the Komagfjord Window, northern Norway. Norwegian Journal of Geology 62, 51-57.

Pharaoh, T.C., Ramsay, D.M. \& Jansen, Ø. 1983: Stratigraphy and structure of the northern part of the Repparfjord-Komagfjord window, Finnmark, Northern Norway. Norges geologiske undersøkelse Bulletin 377, 1-45.

Pharaoh, T.C., Warren, A. \& Walsh, N.J. 1987: Early Proterozoic metavolcanic suites of the northernmost part of the Baltic Shield. Geological Society of London Special Publications 33, 41-58. doi: http://dx.doi.org/10.1144/GSL.SP.1987.033.01.04.

Rastas, P., Huhma, H., Hanski, E., Lehtonen, M., Harkonen, I., Kortelainen, V., Manttari, I. \& Paakkola, J. 2001: U-Pb isotopic studies on the Kittila greenstone area, central Lapland, Finland. In Vaasjoki, M. (ed.): Radiometric age determinations from Finnish Lapland and their bearing on the timing of Precambrian volcanosedimentary sequences, Geological Survey of Finland Special Paper 33, pp. 95-142.

Reitan, P.H. 1963: The geology of the Komagfjord tectonic window of the Raipas suite, Finnmark, Norway. Norges geologiske undersøkelse Bulletin 221, 1-71.

Rhodes, S. 1976: The geology of the Kallak Nappe and its relationship to the N.E. margin of the Komagfjord Tectonic Window, Finnmark, Norway. $\mathrm{PhD}$ thesis, University College of Wales, Cardiff, Unknown.

Rice, A.H.N. 1998: Stretching lineations and structural evolution of the Kalak Nappe Complex (Middle Allochthon) in the RepparfjordFaegfjord area, Finnmark, northern Norway. Norwegian Journal of Geology 78, 277-289.

Rice, A.H.N. 2013: Restoration of the External Caledonides, Finnmark, North Norway. 4 Corfu, F., Gasser, D. \& Chew, D.M. (eds.): New Perspectives on the Caledonides of Scandinavia and Related Areas, Geological Society of London Special Publications 390, pp. 271299. doi: http://dx.doi.org/10.1144/SP390.18.

Roberts, N.M.W., Slagstad, T. \& Viola, G. 2015: The structural, metamorphic and magmatic evolution of Mesoproterozoic orogens. Precambrian Research 265, 1-9. doi: http://dx.doi. org/10.1016/j.precamres.2015.05.031.

Sandstad, J.S. 2010: Microscope and SEM (scanning electron microscope) investigations of thin sections from the Nussir copper deposit. Norges geologiske undersøkelse Report 2010.025, 55 pp.

Sandstad, J.S., Viola, G. \& Nilsson, L.P. 2007: Reconnaissance structural geological mapping and field XRF-analyses of the Ulveryggen copper deposit, Finnmark, Norway. Norges geologiske undersøkelse Report 2007.060, 16 pp.

Sandstad, J.S., Bjerkgård, T., Boyd, R., Ihlen, P., Korneliussen, A., Nilsson, L.P., Often, M., Eilu, P. \& Hallberg, A. 2012: Metallogenic areas in Norway. Geological Survey of Finland Special Paper 53, 35-138.

Siedlecka, A. \& Roberts, D. 1996: Berggrunnskart; Finnmark fylke, scale 1:500 000, Norges geologiske undersøkelse.

Siedlecka, A., Krill, A., Lielingh, B., Often, M., Sandstad, J.S. \& Solli, A. 1985: Lithostratigraphy and correlation of the Archean and Early Proterozoic rocks of Finnmarksvidda and the Sorvaranger district. Norges geologiske undersøkelse Bulletin 403, 7-36.

Smeplass, H.F. 2013: Geological Investigations of the southeastern Part of the Repparfjord Tectonic Window. MSc thesis, Norwegian University of Science and Technology - NTNU, 72 pp.

Smith, M.P., Storey, C.D., Jeffries, T.E. \& Ryan, C. 2009: In Situ U-Pb and Trace Element Analysis of Accessory Minerals in the Kiruna District, Norrbotten, Sweden: New Constraints on the Timing and Origin of Mineralization. Journal of Petrology 50, 2063-2094. doi: http://dx.doi.org/10.1093/petrology/egp069.

Solli, A. 1983: Precambrian Stratigraphy in the Masi Area, Southwestern Finnmark, Norway. Norges geologiske undersøkelse 380, 97-105.

Storey, C.D., Smith, M.P. \& Jeffries, T.E. 2007: In situ LA-ICP-MS 
$\mathrm{U}-\mathrm{Pb}$ dating of metavolcanics of Norrbotten, Sweden: Records of extended geological histories in complex titanite grains. Chemical Geology 240, 163-181. doi: http://dx.doi.org/10.1016/j. chemgeo.2007.02.004.

Stribrny, B. 1985: The Conglomerate-hosted Repparfjord Copper Ore Deposit, Finnmark, Norway: Monograph Series on Mineral Deposits 24, Gebrüder Borntraeger, Berlin, Stuttgart, 75 pp.

Sun, S.-S. \& McDonough, W.F. 1989: Chemical and isotopic systematics of oceanic basalts: implications for mantle composition and processes. Geological Society of London Special Publications 42, 313-345. doi: http://dx.doi.org/10.1144/gsl.sp.1989.042.01.19.

Torgersen, E. 2015: Geological investigations of the Repparfjord Tectonic Window, northern Norway: Backtracking two billion years of geological history by structural analysis, $K-A r$ and ReOs geochronology and carbonate chemostratigraphy. $\mathrm{PhD}$ thesis, Norwegian University of Science and Technology - NTNU, 228 pp.

Torgersen, E. \& Viola, G. 2014: Structural and temporal evolution of a reactivated brittle-ductile fault - Part I: Fault architecture, strain localization mechanisms and deformation history. Earth and Planetary Science Letters 407, 205-220. doi: http://dx.doi. org/10.1016/j.epsl.2014.09.019.

Torgersen, E., Sandstad, J.S., Viola, G. \& Melezhik, V.A. 2014a: Paleoproterozoic sediment-hosted Cu-deposits in western Finnmark, northern Norway. Abstracts and Proceedings, Geological Society of Norway, The Arctic Days Conference,2-6 June, Tromsø, Norway.

Torgersen, E., Viola, G., Zwingmann, H. \& Harris, C. 2014b: Structural and temporal evolution of a reactivated brittle-ductile fault - Part II: Timing of fault initiation and reactivation by $\mathrm{K}-\mathrm{Ar}$ dating of synkinematic illite/muscovite. Earth and Planetary Science Letters 407, 221-233. doi: http://dx.doi.org/10.1016/j.epsl.2014.09.031.

Torgersen, E., Viola, G., Sandstad, J.S., Stein, H., Zwingmann, H. \& Hannah, J. 2015: Effects of frictional-viscous oscillations and fluid flow events on the structural evolution and Re-Os pyritechalcopyrite systematics of $\mathrm{Cu}$-rich carbonate veins in northern Norway. Tectonophysics 659, 70-90. doi: http://dx.doi.org/10.1016/j. tecto.2015.07.029.

Torske, T. \& Bergh, S.G. 2004: The Caravarri Formation of the Katukeino Greenstone Belt, Finnmark, North Norway; a Paleoproterozoic foreland basin succession. Norges geologiske undersøkelse Bulletin 442, 5-22.

Viola, G., Sandstad, J.S., Nilsson, L.P. \& Heincke, B. 2008: Structural and ore geological studies in the northwestern part of the Repparfjord Window, Kvalsund, Finnmark, Norway. Norges geologiske undersøkelse Report 2008.029, 93 pp.

Wood, D.A. 1980: The application of a ThHfTa diagram to problems of tectonomagmatic classification and to establishing the nature of crustal contamination of basaltic lavas of the British Tertiary Volcanic Province. Earth and Planetary Science Letters 50, 11-30. doi: http://dx.doi.org/10.1016/0012-821X(80)90116-8. 
